\title{
Post-Komünist Süreçte Başmüftülük ve Bulgaristan Türklerinin Dinî Hürrriyetleri
}

\section{The Grand Muftiate and Religious Freedom of Bulgarian Turks in the Post-Communist Period}

\author{
Ali HÜSEYINOĞLU* (D), Hayri EMIN*** (])
}

"Doç. Dr., Trakya Üniversitesi Balkan Araştırma Enstitüsü, Edirne, Türkiye

*Doktora Öğrencisi, Trakya Üniversitesi Sosyal Bilimler Enstitüsü Uluslararası İlişkiler Doktora Programı, Edirne, Türkiye

ORCID: A.H. 0000-0002-2101-217X; H.E. 0000-0001-9159-3080

\section{Sorumlu yazar/Corresponding author:} Ali Hüseyinoğlu,

Trakya Üniversitesi Balkan Araştırma Enstitüsü, Edirne, Türkiye

E-posta/E-mail: alihuseyinoglu@trakya.edu.tr

Başvuru/Submitted: 20.01.2021 Revizyon Talebi/Revision Requested: 03.02.2021

Son Revizyon/Last Revision Received: 04.02.2021

Kabul/Accepted: 09.02.2021

Atıf/Citation: Huseyinoglu, Ali ve Emin, Hayri. "Post-Komünist Süreçte Başmüftülük ve Bulgaristan Türklerinin Dinî Hürriyetleri." Yakın Dönem Türkiye Araștırmaları-Recent Period Turkish Studies 39 (2021): 247-287. https://doi.org/10.26650/YTA2021-865431 öz

Balkanların azınlıklarından olan Bulgaristan Türkleri, Bulgaristan’ın bağımsızlığından günümüze bölgedeki diğer Müslüman toplumlarına nazaran farklı evrelerden geçmiştir. Komünist rejimin, Türkçe isimlerin zorla değiştirilmesi gibi en temel insan hak ihlalleriyle gündelik hayatın güçlüklerini tecrübe etmiştir. Bu çalışma, Bulgaristan Türklerinin dinî hak ve özgürlüklerini, komünizm sonrasından günümüze kadar bölgesel, ulusal ve uluslararası yönleriyle derinlemesine bir analizdir. Çalışmanın temel argümanı şudur: Her ne kadar Soğuk Savaş sonrası dönemde Müslüman azınlığın dinî özgürlükleri artmaya devam ediyor olsa da Bulgaristan, 2007'deki AB üyeliğinden günümüze Müslümanların dinî hürriyetlerini tam anlamıyla sağlamamakta; insan ve azınlık haklarıyla ilgili AB normlarını vatandaşları arasında eşit bir şekilde uygulamamaktadir.

Anahtar Kelimeler: Bulgaristan, Avrupa Birliği, İnsan Hakları, Müslümanlar, Dinî Özgürlükler

\section{ABSTRACT}

Bulgarian Turks, one of the minorities of the Balkans have gone through different phases from Bulgaria's independence to the present day compared to other Muslim societies in the region. This community experienced the hardships of daily life through the most basic human rights violations of the communist regime, such as the forced change of Turkish names. This study is an in-depth analysis of the religious rights and freedoms of Bulgarian Turks with their regional, national and international aspects from the post-communist process to present day. The main argument of the study is as follows: Although the religious freedom of the Muslim minority has continued to develop in the post-Cold War period, Bulgaria has not fully ensured the religious freedom of Muslims since its EU membership in 2007 and does not apply EU norms regarding human and minority rights equally among its citizens.

Keywords: Bulgaria, European Union, Human Rights, Muslims, Religious Freedoms 


\section{Extended Abstract}

The Turks in Bulgaria constitute a significant number of citizens in that country. In addition to being one of the historical religions of the Balkan Peninsula, Islam is a wellestablished religion in Bulgaria. The rights of people adhering to Islam have been safeguarded in different ways and times since the end of the 19th century. The very first indication of the rights provided to Muslims goes back to the 1878 Berlin Treaty and that of the very first constitution of the Principality of Bulgaria, namely. Tarnovo Constitution of 1879. These rights would later be strengthened after the establishment of the Kingdom of Bulgaria in 1909, and after the 1913 Peace Treaty of Istanbul with the Ottoman Empire and that of the 1919 Treaty of Neuilly.

In the interwar era, Muslims in Bulgaria largely suffered from a variety of violations of their religious rights and liberties in spite of some positive steps such as the opening of the Nuvvab School in Shumen. The rights of Muslims under the Communist regime throughout the Cold War era would be highly restricted, thus making everyday life totally unbearable for many of them. The totalitarian regime intervened in issues related to Islam as well as its practices among its Muslims citizens. The Bulgarian Communist Party increased its control and power on the offices of the muftiates and that of the Chief Muftiate. Mosques as well as some muftiate offices were closed while the rest of the Muslim religious leaders had to adopt a pro-regime stance in their offices and support Communist policies limiting the rights of their own Muslim congregates.

After a brief historical introduction, this study deals with the main paradigms of the Normative Theory and shows the reader its usefulness to tackle the main research question of this research: How effective has the EU membership of Bulgaria been with regards to the protection and promotion of the rights of Muslims in Bulgaria? As indicated in the title, the main aim of this article is primarily to focus on the religious issues of the Muslims of Bulgaria in the post-Communist regime and to provide a detailed analysis of them from various aspects. This study covers a period of three decades between 1990 and 2020. It primarily concentrates on issues concerning the highest religious body of the Muslims in Bulgaria, namely the. Chief Muftiate since many discussions about Islam in the country are centred around it.

An institution with a history of over a century, the Chief Muftiate is the oldest and most powerful of its kind and deals with a variety of issues concerning its congregates living in different parts of the country. It is the earliest institution of Muslims in which Islam is portrayed in the context of Bulgaria. This research starts by exploring the main 
problematic areas in the functioning of the institution, namely, state-endorsed policies aiming to break the solid leadership of the institution over Muslims. Second, it highlights the monetary problems of the Chief Muftiate and questions the role of fiscal issues on its effective functioning. Third, it continues by emphasizing the role of the Chief Muftiate regarding the protection of those properties belonging to waqf, religious pious endowments of Muslims. This research ends by highlighting the link between the Chief Muftiate and prayer houses located in different parts of Bulgaria which are still in use.

Having studied the abovementioned topics in detail using both local Bulgarian, Turkish and English sources, this study argues that some progress has been made in the area of religious freedom and the rights of Muslims in Bulgaria since the beginning of the post-Communist period. Nevertheless, despite becoming a member of NATO in 2004 and particularly of the EU in 2007, Bulgaria has not fully provided religious liberties to her Muslim citizens for the last thirty years. It seems that Bulgaria prefers not to find a final solution for the on-going violation of religious rights of Muslims, thus failing to promote principles of equality and non-discrimination among her citizens. 


\section{Giriş}

Günümüzde Bulgaristan Müslümanlar Diyaneti Başmüftülüğü (bundan sonra Başmüftülük), bağımsızlık sonrasında ülkedeki Müslüman toplumu etnik aidiyetine ${ }^{1}$ bakmaksızın yurt içinde ve yurt dışında temsil eden, din işlerini yürüten ve düzenleyen, otonom ve halihazırda ileride bahse konu Dinler Yasası'na göre çalışan en önemli kuruluşlarının başında gelmektedir. Tüzel bir kişilik olarak Başmüftülük, faaliyetlerini Bulgaristan Anayasası ile kanunları dâhilinde yürütmekte ve kurumun üst yönetimi seçimle iş başına gelmektedir. Beş yılda bir yapılan Millî Müslümanlar Konferansı'nda (Kurultay), temsilci ve yönetici fonksiyonlarına sahip başmüftü ile kurumun karar mercii olan Yüksek İslam Şurası'nın başkan ve üyeleri seçilmektedir². Başmüftülük, Müslümanlar adına yukarıda sayılan görev ve özellikleriyle salt bir dinî kurumdan çok daha fazlası ifade etmektedir. Düzenlediği sosyal ve kültürel faaliyetlerin yanında diğer dinler ve kültürlerarası ilişkileri ile de öne çıkan hatta gerektiğinde ülke içinde ve dışında insan hakları savunuculuğu da üstlenen önemli bir kuruluştur.

Azınlık haklarının Birinci Dünya Savaşı sonrası Milletler Cemiyeti ile sistemsel bir şekilde koruma altına alınmasıyla Osmanlı'dan sonra Bulgaristan'da kalan Müslüman azınlığın ${ }^{3}$ hakları, uluslararası ve ikili antlaşmaların güvencesine girmiştir. Bu belgelerin ilkleri, sosyal ve siyasi sistemin temelini oluşturan 1878 Berlin Antlaşması ve 1879 Tırnova Anayasası'dır. Bu iki tarihî belge ile Bulgaristan'daki müftülük sisteminin hukuki temelleri atılmış ve dinî bağlamda Müslümanlara bazı hak ve özgürlükler sağlanmıştır ${ }^{4}$. Bulgar devletinin azınlık politikası Berlin Antlaşması'nın hükümleri dışına çıkmayacak olmasına rağmen Tırnova Anayasası'nın oylaması esnasında dönemin mebusları, bu hükümlerin bazılarını anayasaya yansıtmamıştır. Özellikle Berlin Antlaşması'nın dinî aidiyetten dolayı hak kısıtlanması ile ilgili 5. ve 12. maddelerinin esaslar15, Tırnova Anayasası'nda yoktur. Buna benzer maddelerin eksikliği, Bulgar hükûmetlerinin Berlin Antlaşması'nın hükümlerini ileriki yıllarda da görmezden gelmelerini sağlamıştır ${ }^{6}$.

1 Bu toplulukta, kendilerini "Türk" kimliğinin dışında "Pomak", "Roman" veya farklı kimliklerle tanımlayan kişiler de mevcuttur.

2 Başmüftülük Tüzüğ̈̈, Bulgaristan Müslümanlar Diyaneti, Sofya, 2016.

3 Bulgaristan'daki resmî söylem, geçmişte olduğu gibi ülkede sadece Müslümanların varlığından bahsetmektedir.

4 Richard J. Crampton, Bulgaria, Oxford, Oxford University Press, 2007, s. 427.

5 Krasimir Kanev, "Law and Politics toward the Muslims in Bulgaria", Protecting the Human Rights of Minorities in Eastern Europe, eds. Peter G. Danchin, Elizabeth A. Cole, NY, Columbia University Press, 2002, s. 318.

6 Jorjeta Nazırska, Bılgarskata Dırşava I Neynite Maltsinstva 1879-1885 [Bulgar Devleti ve Azınlıkları 1879-1885], Sofya, LIK, 1999, s. 224. 
Osmanlı İmparatorluğu, 19 Nisan 1909 tarihinde İstanbul Protokolü ile Bulgaristan'ın bağımsızlığını tanımıştır. Balkan Savaşlarından sonra 29 Eylül 1913'te, Osmanlı İmparatorluğu ile Bulgaristan Çarlığı arasında İstanbul Barış Antlaşması imzalanmış ve bu iki antlaşmaya ek, müftülüklerle ilgili sözleşmeler yapılmıştır ${ }^{7}$. Müslüman azınlığın haklarının güvence altına alındığı diğer bir belge, 1919 Neuilly Barış Antlaşması'dır. Buna göre Bulgaristan, azınlıkların korunması ile ilgili hükümleri anayasa değerinde sayacağını kabul etmiştir ${ }^{8}$.

İkili ve çoklu antlaşmalar 1şığında o dönemde dinî haklar alanında yaşanan en önemli gelişmelerden biri, din adamı ihtiyacını karşılamak amaçlı Medreset'ün Nüvvab'ın 1922'de Şumnu'da açılmasıdır. 1950'lerin başında din eğitiminin yasaklanmasına kadarki süreçte ciddi sorunlarla karşılaşmış olmasına rağmen ${ }^{9}$ kurum, eğitim faaliyetine devam etmiştir. Aynı antlaşma uyarınca diğer bir önemli gelişme, Başmüftülük kurumunun 1879'dan 1947'ye kadar Dışişleri ve Dinî Mezhepler ${ }^{10}$ Bakanlığı'nın kontrolünde kalmasıdır. Kanev'in ${ }^{11}$ de altını çizdiği gibi ülkedeki farklı dinlerden olan vatandaşların dinî özgürlüklerinin, iç işleri yerine ülkenin dış işleri ile ilgilenen kurumun kontrolüne verilmiş olmasıyla Dışişleri’nin Müslümanların dinî özgürlükleri üzerindeki kontrolü daha da artacak ve 1930'larla birlikte müftülükler, Yalımov'un ifadesiyle adeta “devletin bir peyki" haline geleceklerdi ${ }^{12}$. Ayrıca 18 Ekim 1925 tarihinde Ankara'da imzalanan Türkiye Cumhuriyeti ile Bulgaristan Dostluk Antlaşması ile Ek Protokol ve İkamet Sözleşmesi'nin ek protokolü kısmında ${ }^{13}$, Neuilly Antlaşması'nın azınlıkların korunmasıyla ilgili tüm hükümleri, Dostluk Antlaşması'nın bölünmez parçası sayılmıştır ${ }^{14}$.

Buraya kadar ifade edilen tüm antlaşmalara göre vicdan ve din özgürlügü garanti altına alınmış, vakıf mallarının korunacağı taahhüt edilmiş, müftülük Türk azınlığın bir

7 İsmail Cambazov, 100 Yll Başmüftülük - Tarihçe, Sofya, Bulgaristan Müslümanları Başmüftülüğü, 2011, s. 6.

8 Bilal Şimşir, Bulgaristan Türkleri, 2. bs., Ankara, Bilgi Yayınevi, 2009, s. 488-489; Ali Eminov, "Islam And Muslims in Bulgaria: A Brief History", Islamic Studies, Islam in the Balkans Özel Sayısı, C.36, S.2/3, Islamabad, Islamic Research Institute, International Islamic University, 1997, s. 209-241.

9 İbrahim Yalımov, Istoria na Turskata Obştnost v Bulgaria [Bulgaristan Türk Topluluğu Tarihi], Sofya, IMIR, 2002, s. 248-250.

10 "Mezhepler" ifadesinden kasit, ülkedeki farklı dinlerdir.

11 Krassimir Kanev, "Law and Politics...", s. 319.

12 İbrahim Yalımov, Bulgaristan Türk Topluluğunun Etnokültürel ve Dinsel Kimliği, Sofya, Müslümanlar Diyaneti Başmüftülüğü, 2016, s. 61.

13 Belgelerle Mustafa Kemal Atatürk ve Türk Bulgar İlişkileri (1913-1938), der. Panto Kolev, Cengiz Hakov, Ogniyan Punev, Iliyana Paskova, Liliya Tsvetkova, ter. Elena Mirçeva, Ankara, Başbakanlık Devlet Arşivleri Genel Müdürlüğü, 2002, s. 51-67. Ayrıca bkz. Kader Özlem, “1925 Türkiye-Bulgaristan Dostluk Antlaşması'nın Bulgaristan Türklerinin Azınlık Hakları Bağlamında Analizi”, Prof. Dr. Mehmet Genç’e Armă̆an, ed. Kamuran Reçber, Barış Özdal, Zeynep Özgen, Bursa, Dora, 2016.

14 Bilal Şimşir, Bulgaristan Türkleri, s. 490-491. 
kurumu olduğu ve çalışmalarının Türk ve Bulgar hükûmetleri tarafından birlikte düzenleneceği ifade edilmiştir. Dolayısıyla bahse konu antlaşma metinleri, Bulgaristan' daki Müslüman azınlık olgusunun sadece Bulgaristan'ın bir iç meselesi olmadığını, aynı zamanda bunun bir ikili-uluslararası boyutu olduğunu da vurgulamıştır. Aynı şekilde Osmanlı İmparatorluğu ve daha sonra Türkiye'nin Türklerle olan bağlarını hukuki bakımdan da vurgulamış ${ }^{15}$; bu azınlığın korunmasında anavatan ve garantör ülke olarak söz sahibi olduğunu ve olacağını göstermiştir.

Müslüman azınlığın hak ve özgürlükleri; ilk olarak İkinci Dünya Savaşı sonunda imzalanan 1947 Paris Barış Antlaşması'nda, ardından Bulgaristan’ın 1948'de Birleşmiş Milletler'e (BM) üye olması vesilesiyle İnsan Hakları Evrensel Bildirgesi'nde ve akabinde 1970'lerde imzalanan Avrupa Güvenlik ve İşbirliği Konferansı'na (AGİK) katılımcı ülke olunmasıyla Helsinki Nihai Senedi kabul edilerek tekrar vurgulanmıştır. Böylelikle Bulgaristan, söz konusu hak ve özgürlüklerin korunması konusunda ek uluslararası yükümlülükler altına girmiştir. Fakat Soğuk Savaş’ın ilk yıllarında Bulgaristan Komünist Partisi (BKP), hızlı bir şekilde totaliter yönetime geçiş yaparak azınlık hürriyetlerini kısıtlamaya başlamıştır. Siyasi, ekonomik ve sosyal politikalar ile ülkenin yeni jeopolitiği, Bulgaristan'ın Sovyet Sosyalist Cumhuriyetler Birliği’ne (SSCB) bağlı bir yönetim olmasına sebebiyet vermiştir.

BKP ilk yıllarda, ülkedeki azınlıkları komünist ideolojiye kazandırmak adına eğitim ve kültür alanında farklı çalışmalar yaparken ateist temelli bir eğitim sistemi kurmuştur. Önceki iktidarların azınlıklara yönelik baskıcı politikalarından farklı olarak Türk azınlığa ana dilde eğitim ve kültürel haklar tanıyan BKP, dinî hürriyetlerin kısıtlanması yönünde politikalar uygulamıştır ${ }^{16}$. Fakat bunu yaparken daha önce imzalamış olduğu yukarıdaki antlaşmalarda geçen temel insan hakları prensiplerine gerekli saygıyı göstermemiş; özellikle din ve vicdan özgürlügü, müftülük meselesi ve vakıf malları konusunda önemli ihlaller yaşanmıştır. Bunun ilk göstergelerinden biri, 1949'da çıkarılan Dinî Cemaatler ${ }^{17}$ (Dinler) Yasası kapsamında dinlerin, devletin sıkı kontrolü altına girmesi ile zamanla devlet kurumlarının Başmüftülüğün iç meselelerine önemli oranda müdahale etmesi ve adeta BKP'nin propaganda kurumuna dönüştürülmesidir.

15 Bilal Şimşir, Bulgaristan Türkleri, s. 479-490.

16 Bilal Şimşir, Bulgaristan Türkleri, s. 183-190.

17 Çalışmada “cemaat” dinî kurum, kuruluş veya dinî topluluk anlamında kullanılmıştır. Bulgaristan'da Dinler Kanunu'nda, resmiyeti olması ve kayıtlı tüm dinleri kapsaması nedeniyle "Dinî Cemaatler Kanunu” ifadesi kullanılmaktadır. 
Kısaca belirtmek gerekirse 1879 T1rnovo Anayasası ve 1909 ile 1913'te imzalanan antlaşmalarla müftülüklerle ilgili olarak, yönetimlerinin seçimle göreve gelmeleri prensibi getirilmiş olsa da bu uygulama, farklı dönemlerde ihlal edilmiştir. Özellikle 1930’larda Müslümanların en önemli dinî kurumu Başmüftülük, çeşitli siyasi kararlar sonucu devlet kontrolü altına alınmış; birçok hususta kendi çıkarları doğrultusunda kullanılmaya çalışılmıştır ${ }^{18}$. 1945'ten sonra hazırlanan Bulgaristan Müslümanları Diyaneti tüzükleri (1945 ve 1951) ise ülkede gelişen "yeni sosyalist hayat” koşullarına uygun tasarlanmıştır. Komünizm dönemiyle müftülüklerin ve camilerin çoğu kapatılmış, rejimin tayin ettiği müftüler genelde Türklere yönelik komünist propagandalara destek vermiş ${ }^{19}$ ve vakıf mallarının neredeyse tamamına el konulmuştur. 1949'da yenilenen dinler yasasından sonra 1951'de onaylanan Başmüftülük Tüzüğü ile rejim, Müslümanları etnik esasa göre ayırmış ve iktidarının sonuna kadar onları asimile etmeye yönelik farklı ayrımcılık politikaları izlemiştir² ${ }^{20}$ Diğer azınlık grupları ile kıyaslandığında komünizm uygulamalarından en mağdur grup Müslümanlar olmuştur ${ }^{21}$.

Bulgaristan'daki Türk azınlığın post-totaliter süreçteki varlığı ele alındığında, kurumsal kimliği üç temel alanda ön plana çıkmaktadır: Siyaset, din ve kültür. Bulgaristan Türklerinin siyaset kurumu ve siyasi temsiliyle ilgili konular, bu çalışmanın kapsamı dışında kalmakta ve ayrı bir çalışma konusu teşkil etmektedir. Her iki alanının da birbiri ile birçok noktada iç içe geçtiği göz önünde bulundurularak bazen olayların siyasi yönüne de atıfta bulunacak bu çalışmanın temel amacı, Türklerin dinî özgürlükleri bağlamında en etkili ve en aktif kurum olan Başmüftülükle ilgili temel meseleleri farklı yönleriyle ele almaktır. Bu bağlamda kurum ile ilgili olan ve ülkedeki Müslüman kimliğinin tarihsel varlığını yakından ilgilendiren temel tartışmalar incelenmekte ve geçmişten günümüze, özellikle Soğuk Savaş sonrası süreçte, bu alanda yaşanan temel tartışmalar analiz edilmektedir. Bu bağlamda Uluslararası İlişkiler (UI) disiplininde insan hakları ile ilgili tartışmalarda ön plana çıkan Normatif Teori’nin (NT) temel esaslarından

18 İbrahim Yalımov, "Predizvikatelstvata Pred Muftiyskata Institutsia v İstoriçeski Rakurs [Tarihî Planda Müftülük Kurumunun Önündeki Zorluklar]", 100 Godini Glavno Muftiystvo: Yubileen Sbornik [100 Yıl Müftülük: Jubile Derlemesi], ed. Vedat Ahmed, Sofya, Bulgaristan Müslümanları Başmüftülüğü, 2011, s. 22-35.

19 Carsten Riis, Religion, Politics and Historiography in Bulgaria, NY, Columbia University Press, 2002, s. 21-22; Nuri Korkmaz, "Comparing Bulgarian and Greek Policies for the Integration of Turkish/Muslim Minorities: The Cold War Period”, Bilig, C.90, Yaz 2019, s. 35; Mary Neuburger, The Orient Within: Muslim Minorities and the Negotiation of Nationhood in Modern Bulgaria, Ithaca, Cornell University Press, 2004, s. 163-164.

20 Ulrich Buchsenschutz, Maltsinstvenata politika v Bılgariya: Politikata na BKP kım evrei, romi, pomatsi i turtsi (19441989) [Bulgaristan'da Azınlık Politikalarl: Yahudilere, Çingenelere, Pomaklara ve Türklere yönelik BKP'nin Politikası (1944-1989)], Sofya, IMIR, 2000, s. 30-33.

21 Steven Otfinoski, Nations in Transition: Bulgaria, 2nd ed., NY, Facts on File, 2004, s. 56; Theodora Dragostinova, Between Two Motherlands: Nationality and Emigration among the Greeks of Bulgaria, 1900-1949, Ithaca and London, Cornell University Press, 2011, s. 256. 
faydalanılarak Müslümanların dinî özgürlükleri ile ilgili Bulgaristan'ın attığı adımların, Avrupa Birliği (AB) insan hakları normları esasları ile ne derece örtüştüğü sorgulanmaktadir ${ }^{22}$.

2020 itibariyle Bulgaristan'daki Türklerin dinî özgürlükleri bağlamındaki temel sorunların başında vakıflar, din adamlarının yetersizliği, yeni camilerin inşası ve Osmanlı eseri camilerin restorasyonu gelmektedir. Komünizm sonrası Başmüftülük yönetimlerinin seçimle işbaşına gelmeleri ilkesinin 1992'den sonra tekrar uygulanmaya başlanmasına karşın 1994'te Başmüftülük makamı ile ilgili başlayan dinî temsil eksenindeki tartışmalar, 2011'deki kurultay ile çözüme kavuşma yoluna girmiş ve Bulgaristan'daki Müslümanların en tepe noktadaki dinî temsil kurumu olan Başmüftülüğün seçimle işbaşına gelen yönetimleri tescil edilmiştir.

Çalışma dört bölümden oluşmaktadır: Giriş sonrası ikinci bölümde, çalışmanın teorik çerçevesini çizmek adına NT'nin temel esasları ele alınacak ve araştırma konusuna uygunluğu sorgulanacaktır. Üçüncü bölümde, post-totaliter süreçte dinî özgürlükler detaylı bir şekilde analiz edilecektir. Burada Müslümanların en önemli kurumlarından Başmüftülük ekseninde, 2002 Dinler Yasası'nın Müslümanların dinî özgürlüklerine etkisi irdelenmekte; dinî temsil, vakıf mallarının iadesi ve ibadethane meselesi (yeni camilerin inşası ve Osmanlı eseri camilerin restorasyonu) etrafındaki temel husus ve tartışmalar incelenmekte ve sonuç bölümüyle çalışma tamamlanmaktadır. Bu noktada belirtmek gerekir ki dinî özgürlükler bağlamında bazı hususlar (İslamofobi, ayrımcılık, din eğitimi konusu vd.), farklı çalışmalarda derinlemesine analiz edilmesi adına bilinçli bir şekilde bu çalışmanın dışında bırakılmıştır. Çalışmanın temel argümanı, post-komünist Bulgaristan'da NATO ve AB üyeliği ekseninde, ülkenin Müslüman unsuruna ait dinî hak ve hürriyetlerin tam anlamıyla sağlanmadığıdır. Birtakım sorunlar Bulgaristan makamları tarafından kısmen de olsa çözüme kavuşturulmuşsa da sorunların önemli bir kısmı, hala mutlak çözüme kavuşturulmadan sürüncemede bırakılmaktadır. $\mathrm{Bu}$ da $\mathrm{AB}$ temel insan hakları normlarının Bulgaristan vatandaşları arasında eşit uygulanmadığının önemli bir göstergesidir.

\section{Normatif Teori ve İnsan Hakları}

Aşağıda detaylıca ele alacağımız NT; uluslararası örgütlerin, egemen devletlerin ve farklı aktörlerin, taraf oldukları veya uyguladıkları savaşlar, soykırımlar, iklim sorunları

22 Bulgaristan'ın üyesi olduğu Avrupa Konseyi ve Avrupa Güvenlik ve İşbirliği Teşkilatı'na (AGİT) ait temel insan hakları metinlerinin, Bulgaristan'daki Türklerin dinî hürriyetlerinin korunması üzerindeki etkisi önemlidir. Fakat bu çalışma, normların sadece $\mathrm{AB}$ boyutu üzerinde durmaktadır. 
gibi krizlerin önlenmesi konusundaki ahlaki sorumlulukları ile uluslararası politikanın ahlaki ve etik boyutlarını ele almaktadır. Teorinin Uİ disiplinine yerleşmesi, ana akım teorilere göre oldukça geç olmuştur. NT, Soğuk Savaş’ın sona ermesiyle değişen dünya siyaseti, gelişen yeni olaylar ve büyük tartışmalara neden olan uluslararası gelişmeler sonucu, bazı normatif konular ve etik düşüncelerle ortaya çıkmıştır. Aslında NT; siyaset felsefesi, uluslararası hukuk ve siyaset bilimi gibi çok geniş yelpazede yer alan farklı sosyal bilim dallarında bulunmasından dolayı interdisipliner olup önemli tarihî geçmişi vardır. Bu teorinin kökenleri, Platon, Aristo, Kant, Marx ve Grotius gibi büyük düşünürlere kadar uzanmaktadır. Teorinin özünü oluşturan ahlak, mantık, özgürlük, eşitlik, adalet ve hukuk gibi konular, Romalı Stoacılar'dan Jeremy Bentham gibi faydacılara, Jean-Jacques Rousso, Thomas Hobbes, John Lock gibi sosyal sözleşme kuramcılarına ve daha sonra da Edward Hallett Carr ve John Rawls'a kadar birçok düşünürü meşgul etmiştir.

Normativizm, teorik bir yaklaşım olmaktan ziyade epistemolojik bir tavır alma durumunu ifade etmektedir. Zira normativizmin, pozitivizm ve rasyonalizmle birlikte sosyal bilimlerin üç ana bilgi kuramından biri olduğu söylenebilir. Normativizm, uluslararası ilişkilerin pozitivist bilimsel kimliğine alternatif oluşturabilen zengin felsefi yapısı nedeniyle gereklilikten ziyade zorunluluğu içermektedir ${ }^{23}$. Normatif kuramın analiz düzeyinde, farklı normatif meseleleri farklı perspektiflerden ele alan yaklaşımlar mevcuttur. Bu perspektifler; birey, topluluk/cemaat veya komüniteryen ve bütün dünyayı kapsayan kozmopolit/evrensel boyutu ele alan analiz kademeleridir ${ }^{24}$.

Normlar, NT'de merkezde durur ve teorisyenlere göre bu normların kural koyucu güçleri, aktörlerin belirli durumlarda ne yapmaları ve ne yapmaktan uzak durmaları gerektiğine dair kurulmuş kodlar oluştururken geniş anlamda ahlaki ağırlığa sahiptirler ve ahlaki beklentiler yaratırlar ${ }^{25}$. Normatif teori, ampirik Uİ teorilerinin aksine davranış standartları, yükümlülükler, sorumluluklar, insan hakları, savaş ve barış etiği ve uluslararası adalet dağılımı ile ilgili bireyler, devletler ve uluslararası devlet sistemi konularını ele alır. Bu açıdan NT, dünya siyasetinde normlar, kurallar, değerler ve standartlar ile ilgilenirken; uluslararası hukuk, uluslararası politik ekonomi, diplomasi gibi ilgili alt konular1 ${ }^{26}$ hatta daha fazlasını kapsar. NT'nin ana konusunu, bireylerin içinde yaşadıkları aile, sivil toplum, dinsel kurumlar, devlet ve egemen devletler sistemi gibi sosyal

23 Bilgehan Emeklier, "Uluslararası İlişkiler Disiplininde Epistemolojik Paradigma Tartışmaları: Postpozitivist Kuramlar”, Bilge Strateji, C.3, S.4, 2011, s. 139-184.

24 Paul R. Viotti-Mark V. Kauppi, International Relations Theory, 5th ed., Boston, Longman (Pearson), 2012, s. $392-397$.

25 Toni Erskine, "Normative Theory", International Relations Theories: Dicipline and Diversity, eds. Tim Dunne, Milja Kurki, Steve Smith, Oxford, Oxford University Press, 2013, s. 36-57.

26 Graham Evans-Richard Newnham, The Penguin Dictionary of International Relations, London, Penguin, 1998, s. 328. 
kurumlarla bireylerin değer yargıları arasındaki bağlantının nasıl kurulması gerektiğinin araştırılması oluşturmaktadır. Aynı zamanda NT; hürriyet, eşitlik, adalet, demokrasi, savaş, egemenlik ve benzeri temel normatif kavramların sosyal kurumlarla ilişkilerini incelemeyi de temel sorunsalı olarak kabul etmektedir ${ }^{27}$.

Uluslararası ilişkilerdeki çoğu etkileşimi yönlendiren kurallar, normlardır. Bu normlar, devlet davranışları hakkındaki beklentileri şekillendirir ve bundan sapmaların dikkat çekmesine neden olan standartları belirler. Uluslararası normları tanımlama çabası, yüzyıllar süren bir felsefi geleneği takip eder. Kant ve takipçileri, bağımsız bireylerin veya devletlerin, kendi karşılıklı faydaları için iş birliği yapmasının doğal olduğunu çünkü bunların dar kişisel çıkarları peşinde koşmalarının sonunda herkese zarar vereceğini görebildiğini ileri sürmüştür. Dolayısıyla egemen devletler, her üyenin bağımsızlığına sayg1 gösteren ve onlar üzerinde bir dünya hükûmeti kurmayan yapı ve örgütler yoluyla iş birliği yapabilirler ${ }^{28}$. Diğer yandan egemen devletlerin varoluşlarının temelinde ulusal kimliği oluşturan bazı normatif fikir ve tercihler yatmaktadır. Zira ahlak, kimlik temel ilkesine dayanan bir güç unsurudur. Toplulukçu yaklaşıma göre devlet, egemenliğini vatandaşlarından ve sınırları içerisinde yaşayan bireylerden almaktadır. Bu görüşü savunanlar, egemenlik hakkının kayıtsız şartsız devletin kendisine ait olduğunu ileri sürmektedirler. Buna karşılık evrenselci yaklaşım, bu görüşü tamamıyla reddederek evrensel insan haklarıyla devletin egemenliği kavramını aşmaktadır. NT, insan hakları ile ilgili evrensel bir bakış açısı takınmakta ve toplumun bir üyesi olarak değil ancak özerk birer ahlaki varlık olmaları nedeniyle bireylerin, insan haklarına sahip olduklarını belirtmektedir. Yani insan hakları, mevcut tüm toplumsal düzenlerin üstünde ve onlardan bağımsız olarak var olmaktadır. Toplulukçu yaklaşım, uluslararası politikada müdahale etmeme kuralını benimseyerek uluslararası toplumda düzenin öneminin altını çizerken; evrenselci yaklaşım bir devletin iç işlerine müdahalenin belirli bazı koşullar altında mazur görülebileceğini savunmaktadır. Bu koşulların başında, ülkedeki insan haklarının ve sosyal adaletin korunmasının geldiğini öne sürmektedir ${ }^{29}$.

İnsan haklarıyla ilgili evrenselci yaklaşıma göre bireylerin nerede ikamet ettiğine, milliyetine, yerel, dinsel, etnik veya kabile geleneklerine bakılmaksızın sayg1 duyulması gereken bazı hakları vardır. Toplulukçu yaklaşıma göre ise insan hakları görecelidir. $\mathrm{Bu}$ fikre göre yerel çevre dışındakiler tarafından önemli bulunan bazı

27 Ayşe Zerrin Öztürk, “Uluslararası İlişkiler Teorileri Arasında Normatif Teorinin Yeri ve Kapsamı”, Avrasya Dosyasl, İstihbarat Özel, C.8, S.2, Yaz 2002 (Çevrimiçi), s. 427-444, https://www.researchgate.net/publication/330938169_ULUSLARARASI_ ILISKILER_TEORILERI_ARASINDA_NORMATIF_TEORININ_YERI_VE_KAPSAMI, 29 Aralık 2020.

28 Joshua S. Goldstein-Jon C. Pevehouse, Uluslararası İlişkiler, çev. Haluk Özdemir, Ankara, BB101 Yayınları, 2015 , s. 311.

29 Ayşe Zerrin Öztürk, “Uluslararası İlişsiler Teorileri Arasında...”, s. 439. 
hakların sınırlandırılması anlamına gelse bile yerel geleneklerin ve tarihin dikkate alınması gerekir. Aksi takdirde egemen devletin iç işlerine müdahale olarak algılanır. $\mathrm{Bu}$ durum, insan hakları hukukunu istikrarsız bir zemine oturtmakta ve daha göreceli yönünü yansıtmaktadır ${ }^{30}$. Dolayısıyla devletler, sınırları içerisinde yaşayan bazı gruplara yönelik eşit olmayan davranış ve normatif teorinin vurguladığı ahlak, adalet ve eşitlik gibi değerleri göz ardı edip kendi çıkarlarına ve güvenliğine öncelik verebilir.

Bulgaristan'1n da 2007'den beri üyesi olduğu AB, kurulduğu tarihten günümüze temel insan hakları normlarının oluşturulması, geliştirilmesi ve pratikte uygulanması konusunda önemli yol katetmiştir. AB'nin kurucu belgelerinde bu konunun öneminin altı çizilmesine rağmen bir taraftan AB'ye aday olmak isteyen ülkelere Kopenhag Kriterleri'ne uyma zorunluğunun getirilmiş olması diğer taraftan ise halihazırdaki üye devletlerin kendi vatandaşlarına yönelik ayrımcılık uygulaması ve hak ihlallerinde bulunmaya devam etmesi, birlik normlarının sorgulanmasına sebebiyet vermektedir. Gerek AB'nin gerekse de Avrupa Konseyi ve AGİT gibi kuruluşların bu yöndeki yaptırım mekanizmalarının kısıtlı oluşu, üye ülkelerle ilgili alınan tavsiye ve öneri mahiyetindeki kararları, teori ile pratik arasındaki makasın göstergesidir.

Bazı durumlarda insan hakları fikri, devletlerin egemenlik ve ülkesel bütünlüklerine ters düşebilir. Zira millî güvenlik etmenleri, insan hakları yükümlülükleri ile çakıştığında devletlerin bu hakları yerine getireceği kabul edilmez. Böylece özellikle uluslararası sistemde ülkeler, ahlaki değerlere saygı göstereceğini taahhüt ettiği normları, çıkarları ile güvenlikleri adına üstü kapalı ve dolaylı olarak ihlal eder. Bu durum hem demokratik hem de demokratik olmayan ülkeler açısından geçerlidir ve bazen bu ihlaller normal karşılanır veya görmezden gelinir.

Müslüman azınlık ile ilgili sorunları akademik bağlamda derinlemesine inceleyen Antonina Jelyazkova’ya göre Bulgaristan açısından ülkedeki Müslüman azınlık, bağımsızlıktan itibaren güvenlik meselesi kapsamında ele alınmıştır ${ }^{31}$. Bu azınlık, ülke nüfusunun büyük oranını teşkil etmesinden ve anavatanları Türkiye'nin kapı komşusu olmasından dolayı demokratik dönemde bile devlet egemenliğine tehdit olarak görülmüştür. Ancak Müslüman azınlığın bugüne kadar Bulgaristan’ın bütünlüğünü ve egemenliğini tehlikeye sokacak hiçbir eylemde bulunmamış olması, "kimin 'düşman', kimin 'dost'

30 Joshua S. Goldstein-Jon C. Pevehouse, Uluslararası İlişkiler, s. 349-357.

31 Antonina Jelyazkova, "Dırjavata, Myuftiyskata Institutsiya i Obştestvo v Bılgariya [Bulgaristan'da Devlet, Müftülük Kurumu ve Toplum]”, 100 Godini Glavno Muftiystvo-Yubileen Sbornik [100 Yll Müftülük: Jubile Derlemesi], ed. Vedat Ahmed, Sofya, Bulgaristan Müslümanları Başmüftülüğü, 2011, s. 40-41. 
olduğuna karar veren Bulgaristan devleti"nin ${ }^{32}$ bu yöndeki güvenlik tedbirlerinin rasyonellik açısından sorgulanmasını gerektirmektedir. Burada altı çizilen teorik tartışmalar 1şı̆̆ında bundan sonraki bölümde, araştırmanın temel sorunsalı farklı yönleriyle ele alınacak ve konu ile ilgili temel gelişmeler analiz edilecektir.

\section{Post-Komünizm Dönemi ve Dinî Özgürlükler}

Soğuk Savaş’ın sona ermesiyle yönünü Batı'ya çeviren Bulgaristan, siyasal ve toplumsal sistemini yeniden düzenlerken demokratik bir çerçevede temel insan haklarına ve özgürlüklerine saygılı mevzuatlar geliştirmiştir. Ülkedeki komünist ve totaliter rejimin iktidarına karşı halk ayaklanmaları ve sivil toplum hareketleri -alanında uzman Bulgar akademisyenlerden Mihail İvanov'un da ifade ettiği gibi- 1980'lerin ortalarında, Türklerin asimilasyon sürecine karşı başlattığı direniş ve adalet arayış eylemleriyle başlamış; Bulgarların oluşturduğu demokrasi ve insan hakları çağırısında bulunan sivil hareketlerle devam ettirmiştir ${ }^{33}$. Bu süreç kapsamında bazı araştırmacıların "etnik temizlik" olarak kabul ettikleri politikalar ekseninde ${ }^{34}$ Türklerin hedef alınması, başta Türkiye olmak üzere uluslararası kamuoyundan da ciddi tepki toplamış ve Bulgaristan -BM, AGİK, İKÖ başta olmak üzere- en üst düzeyden ağır eleştiriler almıştır ${ }^{35}$. Bulgaristan Türkleri, 1989 sonrasına gelindiğinde hâlâ bir şekilde devam eden baskılara karşı koyma ve ellerinden alınan kimlikleri ile özgürlüklerini isteme firsatı elde etmiştir. Genellikle Türklerin yaşadığı bölgelerde yapılan barışçıl yürüyüşler ve protestolara iktidar, zırhlı araçlarla ve silahlarla yanıt verirken onlarca Türk de hayatını kaybetmiştir ${ }^{36}$.

1989'daki halk ayaklanmalarından sonra iktidardaki Jivkov rejiminin 400.000'e yakın Türk'ü sınır dışı etmesiyle literatürde sıklıkla değinilen "Büyük Göç” yaşanmıştır 37 . Demokrasiye geçiş dönemi olarak da bilinen post-totaliter dönem, Bulgaristan' da insan hakları mücadelesinin ve siyasi hareketliliğin artmaya başlaması adına önem arz

32 Mümin İsov, "Bulgaristan Tarih Ders Kitaplarında Türk Azınlığın Yerine İlişkin Bazı Gözlemler”, Balkan Araştırma Enstitüsü Dergisi, C.3, S.1, 2014, s. 41.

33 Daniela Gorçeva, “Za 'Vızroditelniya protses' i sıprotivata sreştu nego triabva da pişe v uçebnitsite [Sözde "soyadönüş süreci” ve buna karşı direniş ders kitaplarına yazılmalıdır]”, Liternet, 21 Aralık 2009 (Çevrimiçi), https://liternet.bg/ publish19/d_gorcheva/mihail-ivanov.htm, 2 Şubat 2020.

34 Bkz. Tomasz Kamusella, Ethnic Cleansing During The Cold War: The Forgotten 1989 Expulsion of Turks From Communist Bulgaria, London, NY, Routledge, 2020.

35 Bkz. Ömer Engin Lütem, Türk-Bulgar İlişkileri 1983-1989, Cilt II (1986-1987), Ankara, Avrasya Stratejik Araştırmalar Merkezi (ASAM) Yayınları, 2006; Richard J. Crampton, A Concise History of Bulgaria, Cambridge, Cambridge University Press, 2006, s. 205-211.

36 Bilal Şimşir, Bulgaristan Türkleri, s. 429-438.

371989 öncesi dönemde Bulgaristan Türklerinin Türkiye’ye göçü adına 1950-1951 ve 1968-78 dönemleri arasında iki önemli göç dalgası yaşanmıştır. İbrahim Kamil, Bulgaristan Türkleri ve Göçler, C.I, Ankara, Atatürk Araştırma Merkezi, 2018, s. 85-103. 
ederken; aynı zamanda hükûmetlerin sık değiştiği, çelişkili siyasi dinamiklerin ve istikrarsızlıkların da dönemi olarak bilinmektedir. Dış politikada yönünü Batı'ya çevirmiş Bulgaristan'da Avro-Atlantik kurumlarına üyelik, ülkenin temel hedefleri arasında yer almaya başlamıştır. Ayrıca Bulgaristan' da AB üyeliği sürecinde, birçok alanda mevzuat değişikliği ve reformlar yapılmasına ve iç hukukun uluslararası standartlara uyarlanmasına rağmen etkin bir şekilde uygulanma süreci ağır işlemiştir. ${ }^{38} \mathrm{Bu}$ minvalde ilkin anayasa olmak üzere komünist rejimin demokrasi ilkeleriyle bağdaşmayan yasaları değiştirilmiş; hukukun üstünlüğü ilkelerine dayanarak yeni ve demokratik normlar kabul edilerek yasalaşmıştır. Ülkede ilk defa özgür seçimlerden ve insan haklarından bahsedilmeye başlanmış; kimlik hakkına saygı, ülkedeki azınlıkları korumanın bir göstergesi olmuştur. Eski rejimin azınlık politikaları büyük oranda terk edilirken Bulgaristan’ın onayladığı uluslararası antlaşmaların bazılarına ve 1991 Anayasası'na uygun olarak azınlık gruplarına siyasi, dinî ve kültürel haklar iade edilmeye başlanmıştır. Bu köklü değişimler, ülkedeki Müslüman azınlığını rahatlatıp dinî, siyasi ve kültürel özgürlükler bağlamında daha olumlu bir döneme girmelerini sağlamıştır.

Müslümanların öz belirlemelerine ilişkin en önemli gelişmelerden bir tanesi, önceki rejim tarafından silah zoruyla değiştirilen isimlerin geri alınmasını sağlayan "İsimler Yasası"dır. Ülkenin birçok noktasında yapılan protestolar sonucu 5 Mart 1990'da yasa kabul edilmiştir ${ }^{39}$. Fakat Müslümanların isim sorunu, gelecek 30 yıl boyunca var olmaya ve farklı şekillerde onların gündelik yaşamını etkilemeye devam edecektir.

Demokrasinin ilk yıllarında Müslüman azınlık meselesi, Bulgaristan siyasetini ve toplumunu ayrıştıran en tartışmalı konularından birisi olmuştur. Totaliter rejimin azınlığa karş1 yürüttüğü politikaların 1990'lardan sonra Bulgaristan için ağır bir yük haline gelmeye başlaması nedeniyle özellikle dış politikada imaj düzeltme sürecine gidilmiştir. Çok partili sisteme geçiş döneminde, Türklerden oluşan Hak ve Özgürlükler Hareketi (HÖH) Partisi'nin Ocak 1990'da ülkenin siyaset arenasına çıkması ve ileriki yıllarda meclise girip ülke siyasetinde etkin roller üstlenmesi, özellikle milliyetçi şahıs ve gruplar tarafından büyük bir siyasi memnuniyetsizlikle karşılanmıştır. Ülkenin geleceği ile ilgili müzakereler sürerken $\mathrm{BKP}^{40}$, muhalefetin güçlü sesini kısabilmek için kendisini

381990 sonrasında Bulgaristan, insan hakları ve temel özgürlükler bağlamında birçok uluslararası belgeyi onaylamış ve/veya taraf olmuştur. Anayasa Mahkemesi, Avrupa Konseyi İnsan Hakları ve Temel Özgürlükleri Koruma Sözleşmesi'ne ilişkin olumlu karar vermiş ve 31 Temmuz 1992 tarihinde Parlamento tarafından yasa ile onaylamıştır. Ayrıca Parlamento, Avrupa Konseyi’nin Ulusal Azınlıkları Koruma Çerçeve Sözleşmesi'ni de 1999'da onaylanmıştır. Öte yandan Bulgaristan'ın imzasını atmadığı önemli belgelerden birisi, konseye ait Avrupa Bölgesel Azınlık Dilleri Şartı'dır.

39 İbrahim Yalımov, İstoria na Turskata Obştnost v Bulgaria [Bulgaristan Türk Topluluğu Tarihi], Sofya, IMIR, 2002, s. 485.

403 Nisan 1990 tarihinde Bulgar Komünist Partisi’nin adı Bulgar Sosyalist Partisi (BSP) olarak değiştirilmiştir. 
destekleyen kitlelerin mitingler ve protesto gösterileri yapmalarını teşvik etmiştir. $\mathrm{Bu}$ mitinglerde BKP yetkilileri ve destekçileri, Müslümanlara tanınması öngörülen hakları bir "ayrıcalık" olarak nitelendirmiş; verilen hak ve özgürlüklere açıkça karşı çıkmıştır. Böylece demokrasi döneminin daha ilk yıllarında Müslüman karşıtı Bulgar milliyetçiliği sloganları atılmaya başlanmasıyla birlikte BKP'nin, özellikle milliyetçi oyları mobilize edip Haziran 1990'da yapılan parlamento seçimlerini kazanması sürpriz olmamış$\operatorname{tır}^{41}$. Ayrıca Bulgaristan, Avro-Atlantik kuruluşlar ve kolektif güvenlik sistemlerine dâhil olması yolunda, 1998'de Ulusal Güvenlik Stratejisi Belgesi'ni kabul etmiştir. 2010'a kadar geçerli bu stratejide, bir arada yaşayan farlı etnik grupların farklılaşıp içine kapanmalarının ülkenin ulusal güvenliğine bir tehdit oluşturduğu vurgulanmış ve “dinî ve etnik aşırılığın güçlü demokrasi geleneklerinden yoksun olan yerel topluluklar üzerinde etkisini gösterdiğgi” ifade edilmiştir ${ }^{42}$. Bu stratejinin ileriki yıllarda bazı dinî ve etnik topluluklara, özellikle Müslümanlara yönelik sindirme faaliyetlerinde bulunulması için dış ortaklar nezdinde de bir nevi meşrulaştırıcı girişim olduğu görülmektedir. Nitekim 2007'den sonra uluslararası konjonktürün de etkisiyle özellikle Rodop bölgesinde, ulusal güvenlik servisleri tarafından devletin güvenliğini tehdit eden sözde "radikal unsurlara" yönelik -ciddi gerekçeler olmamasına karşın- birçok operasyon yapılarak çok sayıda kişi gözaltına alınmış veya tutuklanmıştır ${ }^{43}$. Daha sonra bu kişilerin tehlikeli olmadığg anlaşılmış olsa da gerek İslam'a gerekse Bulgaristan'da yaşayan Müslümanlara ve özellikle de halkın seçtiği Başmüftülük kurumuna karşı Bulgaristan kamuoyunda bir güvensizlik algısı oluşturulmaya çalışıldığı not edilmelidir.

\subsection{Yasal Reformlar ve 2002 Dinler Yasası}

Temel haklar ve dinî özgürlüklerle ile ilgili uluslararası antlaşmaların da gerektirdiği gibi 1990'lardan itibaren Bulgaristan tarafindan bazı adımlar atılarak devlet-din ilişkilerini düzenleyen hukuksal çerçeve yeniden oluşturulmuş ve dinî kurumlar özerkliğe kavuşmuştur. Yeni anayasa (1991) -AB ve diğer temel uluslararası standartların da gerektirdiği gibi- 13. maddesiyle dinî kuruluşların bağımsız olduğunu ve dinin devletten ayrı olduğunu taahhüt ederken 6. ve 37. maddeleriyle de vatandaşların düşünce, vicdan ve dinî özgürlüklerini garanti altına almıştır. Dinî toplulukların da devletten ayrı bir statüye sahip olmalarıyla din işlerinde devletin potansiyel müdahalelerine karşı haklar korunmaya başlanmıştır.

41 Fatme Muyhtar, The Human Rights of Muslims in Bulgaria in Law and Politics since 1878, Sofia, Bulgarian Helsinki Committee, 2003.

42 "Reşenie na Narodnoto sıbranie, Strategiya za natsionalna sigursnost [Ulusal Güvenlik Stratejisi ve Meclisin Kararı]", Dirjaven vestnik [Resmî Gazete], no. 46, 22.04.1998, Sofya.

43 Bkz. Evgeniya İvanova, Religiyata kato prestıplenie: Bılgarskata islamska dırjava [Bir Suç Olarak Din: Bulgar İslam Devleti], Sofya, NBU, 2020. 
1991 Anayasası ve yapılan mevzuat değişiklikleriyle asli fonksiyonlarını icra etmesi hususunda hukuki olarak Başmüftülüğün önü açılmıştır. Dinî özgürlükler bağlamında yapılan en köklü değişimler şöyledir: 1997'de düzenlenen Müslümanların Millî Kurultay1, 1998'de Yar1-Yüksek İslam Enstitüsü'nün Yüksek İslam Enstitüsü olmas1, din derslerinin Eğitim Bakanlığı müfredatlarına girmesi, Türkiye Diyanet İşleri Başkanlığı (DİB) ile Bulgaristan Başbakanlık Din İşleri Müdürlüğü arasında ilişkilerin gelişmesi, vd. Bahse konu değişimler; 1997'de başlayan NATO üyelik görüşmeleri, özellikle 1999 sonrası başlayan AB üyelik müzakereleri ve Avrupa Konseyi'nin önerileri doğrultusunda 29 Aralık 2002 tarihinde mecliste kabul edilerek 2003'te yürürlüğe giren yeni Dinler Kanunu ile gerçekleşmiştir ${ }^{44}$. Diğer yandan ilgili kanun, devletin ve yerel yönetimlerin ülkedeki dinlere destek vermesinin önünü açmıştır. Fakat daha önce Başbakanlığa bağlı Dinler Müdürlüğü tarafından dönemsel olarak onaylanan dinî kurumların tescili ve tüzel kişilik kazanmalarına ilişkin yetki, Sofya Şehir Mahkemesi'ne devredilmiştir. Bununla beraber yeni yasa, belirlenen şartları yerine getiren her tüzel kişiye aynı adı ve adresi taşımamak şartıyla "dinî cemaat" 45 kurma imkanı tanımıştır. Bu minvalde 1949'daki haline kıyasla çok daha liberal ve özgürlükçü öğeleriyle ön plana çıkan Dinler Kanunu, ülkedeki dinî hak ve özgürlükler alanındaki eksiklikleri büyük oranda gidermiş; gerek AB, Avrupa Konseyi, ulusal ve uluslararası insan hakları kurumları gerekse de dinî gruplar tarafından kısa sürede benimsenmiştir.

Ancak Dinler Kanunu, özellikle Müslüman toplum için yeni sorunların oluşmasına sebebiyet vermiştir. Kurultay kararlarının tescil yetkisinin Sofya Şehir Mahkemesi’ne devri ve tüm cemaatlere yeni dinî kuruluşlar kurma imkanı verilmesiyle -bu çalışmada da altı çizildiği gibi- Müslüman toplumun temel dinî kuruluşu olan Başmüftülüğün kurumsal kimlik ve gücünün yıpratılması adına gerekli bir suni zemin hazırlanmıştır. $\mathrm{Bu}$ noktada Müslümanların düzenlemiş oldukları dinî yönetim seçimleri ve kurultay kararları -dolayısıyla da dinî kurumun tüzel kişiliğinin yasallığı- Bulgaristan yargısının iradesine bağlı olarak geçerli sayılmaya başlanmıştır. Böylelikle Müslümanların seçtiği dinî liderler ve temsilciler ancak mahkeme kararının onayından sonra resmileşecek, onay alınmadığı takdirde seçimler geçersiz sayılabilecektir. Böylece dinî meseleleri

44 “Dinler Kanunu, 2019”, 2019 (Çevrimiçi), Bulgaristan Cumhuriyeti Başbakanlığı Din İşleri Müdürlüğü, http:// veroizpovedania.government.bg/data/docs/1566950168484.pdf?fbclid=IwAR3LCwq4vTosf342g9sq5Bbvc_uzvGr4sU3PbHwQFqnE1-tRbd1jzqofzY, 10 Ağustos 2020. 2002 yılına ait ana metin, 2019 yılında birkaç değişiklik ile revize edilmiştir. Kanunla ilgili ilk tartışma ve görüşler için bkz. Bulgaristan'da Insan Haklarl, Temel Hak ve Hürriyetler, ed. Bülent Yıldırım, Edirne, Trakya Üniversitesi Yayınları, 2016, s. 125-126.

Dinî kuruluş anlamında kullanılmaktadır. 
sürüncemede bırakabilecek uygulamalara kapı aralanmıştır ${ }^{46}$. Bu da uygulamada Başmüftülük kurumu adına oldukça yorucu ve yıpratıcı birtakım sorunların yaşanmasına sebebiyet verecektir.

\subsection{Dinî Temsilin Meşruluğu Meselesi}

1989'a kadar komünist rejimin ateist ve asimilasyon politikalarının etkisi altında kalan Başmüftülüğün, Soğuk Savaş sonrası dönemde Müslümanların dinî meseleleri ile ilgilenen kifayetli ve bağımsız bir dinî kurum kimliğine kavuşması epey zaman almıştır. Oldukça meşakkatli bu dönüşüm sürecinde Başmüftülük; yarg1 organları, Bulgar hükûmetlerinin ve siyasi partilerin kurumun iç işlerine müdahaleleriyle karşı karşıya kalmıştır. Buna bir de finansal sorunların eklenmesi, Başmüftülüğün kurumsallaşma zorluklarını daha da arttırmıştır. 2019'a kadar devlet yardımının son derece yetersiz kaldığı, aynı zamanda kurumun temel gelir kaynaklarının başında gelen vakıf mallarının iadesi sürecinin oldukça ağır işlediği görülmektedir ${ }^{47}$.

1989 sonrasında Başmüftülük ile ilgili temel sorunların başında, şüphesiz kurum yönetiminin meşruluğu ve dinî liderlik meselesi gelmektedir. 1988-1991 arasında komünist dönemin son başmüftüsü olan Nedim Gencev ${ }^{48}$, totaliter rejimin Bulgaristan Türklerine yönelik uyguladığı zorunlu göç döneminin başında Başmüftü ve Yüksek Din Şurası ${ }^{49}$ Başkanı sıfatıyla ve şura adına yayınladığı bir bildiri ile rejimin politikalarını desteklerken ülkedeki Müslümanların tek vatanları olan Bulgaristan'da dinî hürriyetlerine sahip mutlu bir hayat sürdürdüklerini beyan eden deklarasyonu, kamuoyuna ve Todor Jivkov'a sunmuştur ${ }^{50}$.

46 Vedat Ahmed, "Bulgaristan Müslüman-Türk Azınlı̆̆ı’’nın Dinî Hakları ve Bulgaristan Müslümanları Başmüftülüğü”, 100 Godini Glavno Muftiystvo-Yubileen Sbornik [100 Yll Müftülük: Jubile Derlemesi], ed. Vedat Ahmed, Sofya, Bulgaristan Müslümanları Başmüftülügü, 2011, s. 80-101.

47 Mihail İvanov, "Shtrihi ot Obraza na Bılgarskite Müsülmani-2016 [Bulgaristan Müslümanlarının Yüz Hatlar1-2016]”, Müsülmanite v Bılgariya: Dinamika na Naglasite [Bulgaristan'da Müslümanlar: Eğilim Dinamikleri], ed. E. İvanova, Sofya, NBU, 2017, s. 9.

48 Nedim Gencev - 1945 Razgrad'ın Glocevo köyünde doğmuştur. 1975'den itibaren komünizm döneminde Bulgaristan İçişleri Bakanlığı'nın kadrolu görevlisidir. Gencev, Bulgaristan totaliter rejimin Türklere yönelik yürüttüğü asimilasyon politikalarının uygulamasında ve isim değiştirme kampanyalarında devlet görevlisi olarak aktif çalışmıştır. Rejimin iktidardan düşmesine yakın görevden alınmıştır. 1986'da Kırcaali müftüsü, 1988'den 1992'ye kadar başmüftü olarak görev yapmıştır (İsmail Cambazov, Bulgaristan'da Başmüftülük Tarihi: 1944-2012, İkinci Kitap, Sofya, Bulgaristan Müslümanları Başmüftülüğü, 2013, s. 104).

49 Yüksek Din Şurası'nın adı, 1995'te Yüksek Müslüman Din Şurası ve 1997'de Yüksek Müslüman Şurası olarak değişmiştir.

50 Mustafa Hac1, “Demokratik Değişimlerden Sonra Başmüftülük”, Sofya Yüksek İslam Enstitüsü Yılliğı 2, Sofya, Yüksek İslam Enstitüsü, 2010, s. 5-20. 
Totaliter rejiminin lideri Jivkov'un 1989'da iktidardan çekilmesiyle başbakan olan eski Komünist Partisi (BSP) Dış Ticaret Bakanı Andrey Lukanov, Başmüftü Gencev’i desteklemeye devam etmiştir. Onun aracılığıyla ve seçimlerde Müslüman nüfusun desteğini alma ümidiyle Başmüftü Gencev; Rusçuk, Şumnu ve Mestanlı' daki üç imam hatip lisesi ile Sofya'daki Yarı Yüksek İslam Enstitüsü’nü açılmasını sağlamıştır. Ayrıca müftülüğün yayın organı olan ve o dönemde gazete olarak basılan Müslümanlar ${ }^{51} 1 n$ yayımlanması ile hac organizasyonlarının düzenlenmesi gibi faaliyetlere destek olmuştur. Bunun yanında artık dünyaya açılmış ülkedeki dinî faaliyetlere destek vermek amacıyla yurt dışından farklı vakıf ve kuruluşlar, Bulgaristan Başmüftülüğü’ne mali destek sağlamaya başlamış; fakat desteklerin büyük oranda şahsi çıkarlar için kullanılmış olmasından dolayı tam olarak amacına ulaşmamıştır ${ }^{52}$.

Bu süreçte Başmüftü Gencev’in görevinden alınması için bir grup imam imza toplamış ve Başbakanlık Din İşleri Müdürlüğü’ne sunmuştur. Demokratik Güçler Birliğinin (SDS) ${ }^{53}$ iktidarda olduğu döneme rastgelen bu talep, müdürlüğün olumlu yaklaşımı ile karşılanmıştır. Böylece komünizm döneminde Başmüftülük teşkilatını yöneten kişilerin görevden alınması için ilk adımlar atılmış ve bir Ulusal Müslümanlar Kurultayı düzenlemek amacıyla Başbakanlık Din İşleri Müdürlüğü üç kişilik bir komisyon tayin etmiştir ${ }^{54}$.

Bulgaristan'daki Müslümanların 19 Eylül 1992'de gerçekleştirilen ilk demokratik kurultayı, Kırcaali Bölge Müftüsü Fikri Salih'i başmüftü seçmiştir ${ }^{55}$. Fakat Bakanlar Kurulu'na bağlı Dinler Müdürlüğü tarafından kararın tescili ile ilgili iki yıl boyunca net bir cevap alamadığından dolayı seçilen yönetim faaliyet gösteremeyince derhal yeni bir seçim düzenlenmesi yönünde karar alınmıştır. Ancak ocak ayında yapılması planlanan kurultay, Din İşleri Müdürlügü’nün beklenilmesi yönündeki tavsiyesi ile 6 Mart 1995 tarihine ertelenmiştir. Fakat SDS Hükûmeti istifasını verdiğinden, genel seçim hazırlıkları ve geçici hükûmetin iş başında olması nedeniyle sürünceme devam etmiştir. Bahse konu hukuki ve siyasi boşluktan yararlanan Gencev, 12 Kasım 1994’te kendi kurultayını düzenlemiş; 25 Ocak 1995'te iktidara gelen BSP Hükûmeti’nin de onayı ile ülkedeki

51 Başmüftülüğün bir yayını olan Müslümanlar, yayın hayatına 1989'da gazete olarak başlayan, 2005'te ise dergi olarak devam eden Türkçe-Bulgarca iki dilli, aylık bir süreli yayındır.

52 İsmail Cambazov, 100 Yıl Başmüftülük..., s. 14.

53 Demokratik Güçler Birliği (SDS), 1989'da komünist rejime karşı koyan demokrasi yanlısı sivil toplum kuruluşları ve onların temsilcileri tarafından kurulan, ülkenin demokrasiye geçiş sürecine damgasını vurmuş ve bu süreçte önemli rol oynamış sağ görüşlü bir siyasi koalisyondur.

54 Vedat Ahmed, “Bulgaristan Müslüman-Türk Azınlığı’nın...”, s. 80-101; Ali Dayığlu, "Muslim-Turkish Minority’s Freedom of Religion and Conscience and the Problem of Head Muftiate in Bulgaria Between 1989 and 2011", Journal of Social Sciences, C.5, S.1, 2012, s. 20.

55 İsmail Cambazov, 100 Yll Başmüftülük..., s. 15. 
Müslümanların dinî temsilcisi olarak tanınmıştır. Akabinde Gencev ile taraftarlarının Başmüftü Salih ve ekibini zor kullanılarak Başmüftülük merkez binasından çıkarması üzerine olay savcılığa intikal etmiştir. Savcılık olaya karışmaya hakkının olmadığını belirtirken Başbakanlık Dinler Müdürlüğü ise Salih'e artık başmüftü olmadığını resmî yazıyla bildirmiştir. Salih, Yargıtay’a yaptığı itirazının 22 Temmuz 1995 tarihli kararla reddedilmesi üzerine ${ }^{56}$ başmüftünün meşruluğu meselesini Avrupa İnsan Hakları Mahkemesi'ne (AİHM) taşımış ve Bulgaristan, Müslümanların dinî işlerine müdahalesinden dolayı mahkûm edilmiştir ${ }^{57}$. Böylelikle halkın seçtiği Başmüftülük yönetimine paralel bir yönetimin kurulmasıyla fiili olarak Bulgaristan'da Müslümanlarının dinî temsil sorununun temelleri atılmıştır.

Halkın seçtiği Başmüftülük daha önce planlandığı gibi olağanüstü kurultayı, 6 Mart 1995 'te her şeye rağmen düzenlemiştir. Kurultayın, bir önceki seçimleri tasdik ederek Salih'i bir kez daha başmüftü seçmesi üzerine kararların onaylanması için Başbakanlık Dinler Müdürlüğü'ne başvurulmuştur. Başvuruya cevap alınamaması sebebiyle ikinci kez başvurulmuş, yine cevap alınamayınca olay mahkemeye taşınmıştır. Mahkeme, 14 Ekim 1996 tarihli kararıyla Dinler Müdürlüğü’nün dilekçeyi tekrar gözden geçirmesini istemiştir ${ }^{58}$. Gencev, aynı zamanda tescilini garanti altına almak adına tüzük değişikliği yaptığı yeni bir kurultay düzenlemiştir. Dinler Müdürlüğü tarafından onaylanan bu tüzük $^{59}, 20$ y1l boyunca hukuki olarak resmiyeti olan tek tüzük olmuş, tüm kurultaylar ve seçimler buna göre yapılmıştır. Her ne kadar tüzüğü değiştirecek kurultaylar yapıldıysa da ilgili merciler tarafindan tescil edilmeyip resmiyet kazanmamasından dolayı kurultaylar geçersiz sayılmıştır.

1997'de yeniden iktidara gelen SDS Hükûmeti, iki taraf (halkın seçtiği yönetim ve Nedim Gencev) arasında görüş birliğinin sağlanması ve birleşmeleri yönünde girişimde bulunmuştur. Birleştirici bir kurultayın yapılması için karşılıklı anlaşma sağlanmış olsa da Gencev, kurultaya katılmaktan son anda vazgeçmiştir. Buna rağmen düzenlenen kurultay sonucunda başmüftü olarak Mustafa Hacı, Yüksek İslam Şura Başkanı olarak da Hüseyin Karamolla seçilmiştir. Seçilen yönetimler, dönemlerini başarıyla tamamladıktan sonra 2000 ve 2003 'te tekrar kurultaylar düzenlenerek seçimler yapılmıştır. Fakat 2002'den beri yürürlükteki yeni Dinler Kanunu'na göre kurultay kararlarını ve seçilen

56 İsmail Cambazov, Bulgaristan'da Başmüftülük Tarihi..., s. 148-149.

57 HASAN and CHAUSH v. Bulgaria, no. 30985/96 (Grand Chamber Judgment)", 26 Ekim 2000 (Çevrimiçi), https:// www.echr.coe.int/Pages/home.aspx?p=home, 28.10.2020.

58 İsmail Cambazov, Bulgaristan'da Başmüftülük Tarihi..., s. 149.

59 Bulgaristan Müslümanlar Diyaneti Başmüftülüğ̈̈ Arşivi (BMDBA), Mahkeme Davaları Bölümü (MDB), Sofya Bölge Mahkemesi, Dava Kararı no. 2402/2008. 
yönetimleri Başbakanlık Din İşleri Müdürlüğü yerine Sofya Şehir Mahkemesi tescil etmektedir. Bu noktada mahkeme, Gencev'in de itirazlarıyla üst mahkemenin daha önce aksi yönde aldığı karara rağmen Müslümanların kolektif iradesini dikkate almayarak 1997 'den beri seçilen yönetimleri usulsüzlük ve farklı ihlaller gerekçeleriyle tescil etmemiştir ${ }^{60}$. Bunun üzerine yeni kurultay yapılması için girişimlerin başlatılması sebebiyle mahkeme, Müslümanlar arasından üç kişilik bir komisyon tayin ederek 2005'te yeniden kurultay düzenlenmiştir. Başmüftü olarak Mustafa Hacı'nın, Şura Başkanı olarak ise Basri Pehlivan'ın seçilmesi, Sofya Şehir Mahkemesi tarafından tescil edilmiştir. Ancak uzun mahkeme süreci sonucunda 2005, 2008 ve 2009'da düzenlenen olağanüstü kurultaylar, Gencev'in itirazları dikkate alınarak ve farklı usulsüzlük gerekçeleriyle mahkemece reddedilmiş ve dava üst mahkemelere sevk edilmiştir ${ }^{61}$.

Mayıs 2010'da verdiği karar ile Yargıtay, 1996 Tüzüğü’ nü esas alarak eski rejimin müftüsü Gencev'in Müslümanların yasal temsilcisi olduğu kararını çıkarmıştır. Mahkemenin kararı sonrası Gencev, bir hafta sonu özel icra yargıcı ile polisin desteği ve özel güvenlik ekiplerini getirmek suretiyle Başmüftülük Merkez Binası'na gelerek bölge müftülüklerini de kontrolü altına almaya çalışmıştır. Bunun üzerine basına da yansıdığı gibi ülkenin farklı noktalarından Müslümanlar, Sofya'da bulunan Başmüftülüğe akın ederek Gencev’i Başmüftülük binasından çıkarırken diğer bölgelerdeki müftülük binalarını savunmak için de harekete geçmiştir ${ }^{62}$. Savcılığın vermiş olduğu karar sonucunda Başmüftülük aylarca kapalı kalmış, Müslümanlar seçtikleri dinî liderlerine sahip çıkmış ve birçok gönüllü dinî kurumlarda aylarca nöbet tutmuştur ${ }^{63}$.

Başmüftülük yönetimi, durumu ulusal kurumların yanı sıra AB, BM, İslam İşbirliği Teşkilatı, Avrupa Konseyi, AGİT gibi uluslararası kurum ve kuruluşlara bildirerek destek çağrılarında bulunmuştur. Aynı yıl ülkenin birçok il merkezinde başta imamlar olmak üzere Müslüman toplumuna mensup kişiler, Yargıtay’ın kararını protesto etmiştir ${ }^{64}$. Yine HÖH'ün temsilcileri tarafından; hükûmetin meclis çatısı altında "Nedim Gencev gibi bir zorbayı el altından" desteklediği, 210 bin Müslümanın imzasını dikkate alınmadığı, Başmüftülüğün iç işlerine müdahale edildiği ifade edilerek AB kurumlarına bilgi

60 Mustafa Hacı, "Demokratik Değişimlerden Sonra...", s. 5-20

61 İsmail Cambazov, 100 Yll Başmüftülük..., s. 17-22.

62 Stela Stoyanova, "Zapeçataha Glavno Muftiystvo: Çasten Sıdeben İzpılnitel Vleze s Policiyata v Sgradata [Başmüftülüğü mühürlediler: Özel icra hakimi polisle birlikte binaya girdiler]”, Dnes.bg, 27 Kasım 2010 (Çevrimiçi), https://www. dnes.bg/obshtestvo/2010/11/27/zapechataha-glavnoto-miuftiistvo.104925,6, 29 Mart 2020; Ali Hüseyinoğlu tarafından Mustafa Hacı ile yapılan mülakat, Sofya, 19 Kasım 2019.

63 İsmail Cambazov, Bulgaristan'da Başmüftülük Tarihi..., s. 296-297.

64 BMDBA, Dış İlişkiler Bölümü (DİB). 
verildiği ve gerekeni yapacaklarının bildirildiği yönündeki ifadeleri basında yer almış$\operatorname{tır}^{65}$. HÖH AP Milletvekili Metin Kazak ve diğer vekiller, meseleyi Avrupa Parlamentosu'nda gündeme getirmiş ve Avrupa Komisyonu'na soru önergesi sunmuştur. Önergeyle dinî toplulukların öz yönetim ve dinî özerklik haklarının onaylayıp onaylamadığı, Bulgar devletinin son derece hassas olan dinî özerklik ve özyönetim hakkına müdahale etmesinin kabul edilebilir görülüp görülmediği sorularına komisyondan yazılı cevap talep edilmiştir ${ }^{66}$.

Adalet ve Temel Haklardan Sorumlu Bakan Viviane Reding, komisyon adına verdiği yazılı cevapta, komisyonun Avrupa Birliği Temel Haklar Şartı'nın 10. ve 21. maddelerinde belirtildiği gibi din özgürlüğüne saygıyı ve kişinin dinine veya inancına dayalı ayrımcılık yasağını kayıtsız şartız desteklediğini; dinî toplulukların hukuki statüsünün ve liderlerinin atanmasının AB'nin işleyişi hakkındaki Antlaşma'nın 17. maddesinde açıkça belirtildiği üzere AB üye devletlerinin münhasır yetkisine giren konular olduğunu, bu durumda temel haklara sayg1 gösterilmesini ve ulusal yasaları ve uluslararası yükümlülüklerine uygun olarak etkin bir şekilde korunmasını sağlamanın üye devletlerin sorumluluğunda olduğunu ifade etmiştir ${ }^{67}$.

Dinler Yasası'na dayanarak ülkedeki imamların, encümenlik üyelerinin ve Müslüman toplumun önemli bir kısmının (210.000 kişi) imzalı talebi üzerine 12 Şubat 2011'de kurultay düzenlenmiştir. Olağanüstü Ulusal Müslüman Kurultayı sonucunda Dr. Mustafa Hacı yeniden başmüftü, Şabanali Ahmed ise ikinci defa şura başkanı seçilmiştir. Müslümanların seçmiş oldukları dinî temsilciler, beş yıllık yönetim sürelerini başarıyla tamamlamış; 24 Ocak 2016'da olağan Ulusal Müslümanlar Kurultayı düzenlenmiş, mahkeme ise seçim kararlarını onaylamıştır ${ }^{68}$. Böylece Gencev’in Müslümanların düzenlediği kurultaylar hakkında mahkemeye yaptığı itirazlar başarısız olurken iddialarının artık hukuki bir dayanağı kalmamıştır. Bu noktada eklemek gerekir ki

65 Tanya Petkova, “DPS: Vlastta mılçalivo poddırja 'uzurpatora' Nedim Gencev [Hükûmet 'gaspçı' Nedim Gencev’i sessizce destekliyor]”, Mediapool.bg, 24 Eylül 2010 (Çevrimiçi), https://www.mediapool.bg/dps-vlastta-malchalivo-poddarzhauzurpatora-nedim-gendzhev-news170351.html?fbclid=IwAR2rCMFZgeDcFeDV2MVwdKm9Nx8GYx9NIDfj57YsSs QeZmWWbdrNIBKqgM, 21 Nisan 2020.

66 "Parliamentary questions, E-4794/2010, Question for written answer to the Commission, Rule 117, Metin Kazak (ALDE), Carl Haglund (ALDE) and Sophia in 't Veld (ALDE)", 30 Haziran 2010 (Çevrimiçi), https://www.europarl. europa.eu/sides/getDoc.do?pubRef=-//EP//TEXT+WQ+E-2010-4794+0+DOC+XML+V0//EN\&language=EN, 10 Nisan 2020.

67 "Parliamentary questions, E-4794/2010, Answer given by Mrs Reding on behalf of the Commission", 27 Ekim 2010 (Çevrimiçi), https://www.europarl.europa.eu/sides/getAllAnswers.do?reference=E-2010-4794\&language=EN, 10 Nisan 2020.

68 "Sofya Şehir Mahkemesi 24 Ocak 2016 tarihli kurultay kararlarını onayladı”, 10 Şubat 2016 (Çevrimiçi), Bulgaristan Başmüftülüğ̈̈, https://www.grandmufti.bg/bg/up-to-date/novini/2218-sofiiski-gradski-sad-registrira-natzionalnatamyusyulmanska-konferentziya-ot-24-yanuari-2016.html, 8 Eylül 2020. 
Gencev'in 1996'da düzenlediği kurultay ve sonucunda kabul edilen tüzük, 20 yıl boyunca yasaların ve kurumların tanıdığı en sonuncular olmuştur. Çünkü 1996 sonrası düzenlenen diğer tüm kurultaylara Gencev mahkemede itiraz edip kazanmış, 2016'ya kadar kurultayların her defasında 1996 Tüzüğü temel alınarak düzenlenmeleri gerekmiştir $^{69}$. Bu açıdan kurultaylar artık 2016 Tüzüğü’nü temel alacağ1 için 2016 Kurultayı, Başmüftülük ve Müslüman azınlık için dönüm noktası olmuştur.

Kısacası Gencev, mahkemede davalarını ve kurumları kazanmış olmasına karşın Müslümanların desteğini kazanamamıştır. Çoğu kurultay ve seçimin yalnızca kağıt üzerinde yaptığı herkes tarafından bilinmesine rağmen alınan kararlar Bulgaristan makamlarınca onaylanmıştır. Tüm bu gelişmeler yaşanırken Müslümanların seçtiği kişiler ise kendilerini mahkemeye seçilmiş dinî lider olarak tescil ettirememişlerdir ${ }^{70}$. Mahkeme kararına gerekli itirazların yapılması ve yeni bir kurultayın düzenlenmesinin Bulgaristan'ın AB üyeliği dönemi sonrasına denk gelmesi, bu çalışma adına önem arz etmektedir. AB normlarına uyum ve temel insan ve azınlık haklarının korunmasını esas alan Kopenhag Kriterleri göz önüne alındığında, Müslümanların bazı vakıf mallarının iadesi gibi temel dinî meseleler alanında önemli adımlar attıkları fark edilecektir.

Tüm bu gelişmeler 1şı̆̆ında din ile siyasetin Bulgaristan'daki Müslüman nüfus adına önemi ve bunun dinî özgürlüklerin iadesi bağlamındaki etkisini kısaca sorgulamak, bu çalışma adına önemlidir. Azınlık toplumlarında sıklıkla görülen din ile siyasetin iç içe geçmesi ve birbirini beslemesi, Bulgaristan'daki Müslümanlar için de geçerlidir. Komünizm sonrası dönemde HÖH Partisi'nin Bulgaristan'daki temel siyasi aktörlerden biri olması ve bazı dönemlerde hükûmet ortaklığı yapması, Türklerin dinî özgürlükleri ile bazı sorunların çözüme kavuşmasında şüphesiz önem arz etmektedir.

Dinî temsil ile ilgili sorunların AB üyeliği sonrasında da devam etmesi, mahkemenin yıllarca seçim kararlarını tescil etmekte direnip ülkedeki Müslüman vatandaşların dinî temsili ile konuları sürüncemede bırakması ve Bulgaristan Müslümanlarının tamamına yakını tarafından reddedilmesine rağmen totaliter rejimin başmüftüsünü geri getirmesi, AB'nin Bulgaristan üzerindeki normatif gücünün azınlık haklarıyla ilgili her alanda aynı derecede hissedilmediğinin önemli bir göstergesidir. AB'nin bu yöndeki yaptırım mekanizmalarının, kısıtlı ve tavsiye mahiyetinde olmasının da ötesinde genellikle yerel hükûmetlerin safında yer almayı tercih ettiği görülmektedir. Yani AB, azınlık hakları gibi etik ve ahlaki normların yerel ve ulusal alanda ihlalini, üye ülkelerin çıkarları adına

69 Mustafa Hacı, “Demokratik Değişimlerden Sonra...," s. 5-20.

70 Mustafa Hacı ile yapılan 19 Kasım 2019 tarihli mülakat. 
göz ardı edebilmektedir. Ayrıca bireysel insan haklarına saygı gösteren bir yapıya sahip olduğundan dolayı bireylerin maruz kaldığı hak ihlalleri olaylarının AİHM'de ele alınmasını desteklemekte, topluluk haklarının netliğe kavuşturulmasını üye devletlere bırakmakta ve normlar üzerinde sadece yorum yapmakla yetinmektedir. Her ne kadar Bulgaristan Müslümanlarının dinî özgürlükleri, $\mathrm{AB}$ için önem teşkil etse de Bulgaristan'ın siyasi ve ekonomik istikrarı gibi yüksek meselelerin daha ön plana çıktığ1 görülmektedir.

2003-2011 dönemine kıyasla 2011 sonrası seçimlerin ve kurultay kararlarının Sofya Şehir Mahkemesince sorunsuz bir şekilde tescil edilmesi, Müslüman azınlığın dinî hürriyetlerine ve Başmüftülüğün yasal statüsüne ilişkin temel sorunların, AB üyeliği sonrası bir çözüme kavuşmuş olduğunun önemli bir göstergesidir. Aynı zamanda Başmüftülük krizinin, Bulgaristan'ın 2007'de AB üyesi olmasından sonraki dönemde de uzun süre devam etmesi, Avrupa İnsan Hakları Sözleşmesi'nin ve AB Temel Haklar Şartı'nın ihlal edildiğini ve evrensel değerlerin ve normların savunucusu olduğunu iddia eden AB'nin bu konuda somut bir çözüm geliştiremediğini göstermektedir. Fakat Müslüman azınl1ğın dinî liderlik ve temsil konusunda edinmiş olduğu ve bu çalı̧mada altı çizilen kolektif tecrübe, dinî özgürlüklerle ilgili konularda daha tedirgin ve dikkatli olacağı yönündeki öngörüleri kuvvetlendirmektedir.

\subsubsection{Başmüftülüğğün Mali Sorunları}

1990 sonrasında Başmüftülüğün en ciddi sorunlarından birisi, finansal yetersizliktir. Gelirlerinin ana damarını teşkil eden vakıf mallarının demokrasiye geçilmesine rağmen başından beri tam anlamıyla geri alınamaması, kurumun maddi açıdan dışa bağımlı hale gelmesinin en önemli sebebidir. Sürekli maddi sıkıntılar çeken Müslümanların dinî kurumları, çeşitli kaynaklardan gelen bağışlar sayesinde rutin faaliyetlerini uzun yıllar yürütse de bazı dönemlerde çalışanların maaşlarının bile ödenemediği olmuştur ${ }^{71}$.

1998'de Dinler Kanunu'nda yapılan değişikliklerle devlet bütçesinden dinî topluluklara mali yardımlar yapılması sağlanmıştır. Her yıl az miktarda artan yardımlar, dinî toplulukların ülke nüfusuna orantısı ve sayım sonuçları göz önünde bulundurularak tahsis edilmektedir. Örneğin 2001'de dinî topluluklara 1 milyon leva yardım tahsis etmiştir. Bu yardımdan 880.000 leva Ortodoks kilisesine, 20'şer bin leva Ermeni ve Yahudi topluluklarına, 100.000 leva ise Müslümanların dinî kurumu olan Başmüftülüğe sağlamıştır $^{72}$. Ancak yapılan bu destek, ibadethanelerin tadilatı adı altında olup genellikle

71 Hayri Emin tarafindan Murat Pingov ile yapılan mülakat, Sofya, 17 Şubat 2020.

72 “Devlet Bütçesi Yasası, 2001”, 2001 (Çevrimiçi), Maliye Bakanlığı, https://www.minfin.bg/bg/264, 11 Eylül 2020. 
belediyeler vasıtasıyla gönderildiğinden Başmüftülük, ona bağlı bölge müftülükleri ve eğitim kurumları, kurumsal işleyişine yönelik temel bütçe dışında kalmıştır ${ }^{73}$. Bu sebeple 17 Haziran 1998 tarihinde DİB ile Bulgaristan Başbakanlığı Dinler Müdürlüğü arasında Başmüftülügüün dinî okullarının finansmanına çözüm getiren bir sözleşme imzalanmıştır. Sözleşme kapsamında DİB, Başmüftülüğün üç imam hatip lisesine ve Sofya'daki İslam Enstitüsü'ne din eğitimi hocaları gönderecek, dinî literatür sağlayacak ve mali yardımlarda bulunacaktır. Karşılıklık ilkesiyle Türkiye’deki Bulgar Ortodoks toplumunun sorunlarının giderilmesi de sözleşmede yer almaktadır ${ }^{74}$. Sözleşme çerçevesinde yapılan tüm faaliyetler, Bulgaristan devletinin ve yetkili kurumların bilgisi ile kontrolü dâhilinde olduğundan yasada öngörülmeyen bir faaliyetin yapılması söz konusu değildir. Sözleşmeye ek olarak Türkiye Diyanet Vakfı ile Bulgaristan Başmüftülüğü arasında bir iş birliği protokolü de imzalanmıştır ${ }^{75}$.

2011 sonrasında, tam da dinî temsil bağlamında temel sorunlar çözülmeye ve Başmüftülük kurum olarak toparlanmaya başlamışken birtakım ekonomik sorunlar yeniden ortaya çıkmıştır. İlk olarak Maliye’ye bağlı kurumların, Başmüftülüğe ve şubelerine yaptığı mali teftişler sonucu Başmüftülüğün yaklaşık 1,5 milyon leva vergi borcu olduğu tespit edilmiştir. Borçların artmasına, yıllar içinde Başmüftülük yönetimlerinin yasal statüsüne ilişkin yürütülen davalar da sebep olmuştur. Halkın seçtiği yönetimlerin resmiyet kazanma çabaları yürüttüğü dönemlerde çalışanlarının sigortalarını ve vergilerini ödeyemeyen Başmüftülük, kurum olarak Mali Usulsüzlüklerle Mücadele Yasası'na takılmıştır. Bu yıllarda Başmüftülük kurumunun yıllık bütçesi yaklaşık 1 milyon levadır ${ }^{76}$. Sonraki yıllarda bu vergi borçları katlanarak çoğalmıştır.

İkinci olay, 2016'da hükûmetin istifa etmesinin ardından Ocak 2017'de oluşturulan ve Mayıs 2017'ye kadar görevde kalan geçici hükûmet döneminde cereyan etmiştir. Güncel siyasi gelişmelerin de etkisiyle 1998'de DİB ile Bulgaristan Başbakanlığ1 Din İşleri Müdürlügü arasında imzalanan protokolü, Bulgaristan'ın tek taraflı olarak feshetmesi sonucunda Başmüftülük, yeni bir finansal sorunla karşı karşıya bırakılmıştır. Geçici hükûmetin başbakanı Ognian Gercikov, gazetecilerin konuyla ilgili sorularına, böyle bir kararı hatırlamadığı yanıtını vermiş olsa da yaklaşık bir yıl süren kriz boyunca Başmüftülüğe bağlı birçok din görevlisi ve imam olumsuz etkilenmiş, hatta maaşlarını

73 Murat Pingov ile yapılan 17 Şubat 2020 tarihli mülakat.

$74 B M D B A, D I B$.

$75 B M D B A, D \dot{I} B$.

76 BMDBA, Mali Işler Bölümü (MİB); BMDBA, Vakıflar Bölümü (VB). 
alamadıklarından dolayı görevden ayrılanlar olmuştur ${ }^{77}$. Geçici hükûmet döneminde Başmüftülüğün borçları bahane edilerek, 2001'de Başmüftülük tarafından satın alınıp ve üzerine idari, eğitim ve kültür merkezi inşa edilmesi planlanan Sofya'nın Malinova Dolina'daki araziye, Ulusal Gelirler Ajansı (NAP) haciz koyarak satışa çıkarmış ${ }^{78}$; fakat uzun müzakere ve uğraşlar sonucu bu satış gerçekleşmemiştir.

4 May1s 2017'de iktidara gelen koalisyon hükûmeti döneminde, benzer bir tutumla 2018'de Sofya'nın Bankya ilçesinde bulunan ve Yüksek İslam Enstitüsü binası için öngörülen bir vakıf gayrimenkulü, yine kurumun borçları bahane edilerek NAP tarafından haciz konarak değerinden çok düşük bir fiyata satılmıştır ${ }^{79}$. Ayrıca milliyetçi partiler tarafindan desteklenen "Borisov 3 Hükûmeti" 80 , kanunlarda bazı değişiklikler yaparak dinî kuruluşların finansman sorununu yasal düzenlemelerle gidermeye çalışmıştır. Siyasi partiler, 2018' de millî güvenliğe yönelik tehditlerin ve "dinî radikalizm”in ülkeye girmesini önlemek adına, Dinler Kanunu'nda değişiklikler yaparak dinî cemaatlere daha fazla yardım yapılmasını ancak yurt dışından finansal yardım almalarının yasaklanmasını önermiştir ${ }^{81}$. Bu noktada hükûmet ortağı milliyetçi partilerin rolünün altını çizmek gerekmektedir. Yıllardır DİB’ten aldığ 1 yardımların kesilmesini ve belirli zamanlarda gönderilen din görevlilerin gelmesini engellemek isteyen milliyetçi partiler, son yıllarda mülteci meselesini de bahane edip yabancı unsurların ülkeye girmesini, radikalizmin önlenmesini ve millî güvenliğin korunmasını gerekçe göstererek devletin dinî kurumlar üzerinde daha sıkı kontrol sağlaması yönünde yasa değişikliği girişimlerinde bulunmuşlardır. Ayrıca bu tasarılarda dinî kuruluşlar ve topluluklara getirilen; yabancı kuruluşlar ve vatandaşlardan bağış alma, yabancı kuruluşlarla iş birliği kurma, ibadetleri sadece Bulgar dilinde yapmaları gibi birçok kısıtlamalar da dikkat çekmektedir. Bahsi geçen tasarılarda da \%1'in üzerindeki dinî topluluklara devlet bütçesinden kişi baş1 10 leva destek verilmesi öngörülmektedir ${ }^{82}$.

77 Murat Pingov ile yapılan 17 Şubat 2020 tarihli mülakat.

78 Zornitsa Stoilova, "Kak Bılgarskite imami ostanaha bez pari [Bulgaristan imamları nasıl parasız kald1]", Kapital, 8 Haziran 2017 (Çevrimiçi), https://www.capital.bg/politika_i_ikonomika/bulgaria/2017/06/08/2985260_kak_ bulgarskite_imami_ostanaha_bez_pari/, 20 Nisan 2020.

$79 B M D B A, M i B$

80 Başbakan Boyko Borisov, 2017'de üçüncü kez başbakan olarak göreve gelmiştir. Bundan dolay1 "Borisov 3 Hükûmeti” ifadesi kullanılmaktadır.

81 “Dinler Kanunu Önerileri, no. 854-01-34”, 4 Mayıs 2018 (Çevrimiçi), Bulgaristan Parlamentosu, https://www. parliament.bg/bg/bills, 13 Haziran 2020.

82 “Dinler Kanunu Tasarısı, no. 854-01-35" 9 Mayıs 2018 (Çevrimiçi), Bulgaristan Parlamentosu, https://www.parliament. bg/bg/bills/ID/78070, 13 Haziran 2020. 
Ülkedeki dinlerin sadece iki tanesi \% 1 üzerinde nüfusa sahip olduğuna göre bu kısıtlamanın Ortodoks Hristiyan çoğunluktan ziyade yurt dışından resmî finansal destek alan Müslüman azınlık ve ona ait Başmüftülük kurumunu hedef aldığı açıkça görülmektedir. Böylelikle Başmüftülük, son derece İslamofobik gerekçeleri barındıran bu tasarılara yaz1lı bildirgelerle tepki göstermiştir ${ }^{83}$. Yurt dışından yardımların kesilmesi önerisi, diğer dinî grupları da rahatsız etmiştir. Çünkü gelirlerinin önemli oranı yurt dışından sağlanmaktadır. Yasa tasarıları; Ortodoks, Katolik, Protestan ve Musevi cemaat üyelerinin tepkileri ve onları destekleyen halkın düzenlediği protestolar ${ }^{84}$ sonucu reddedilmiştir. Sonuç olarak Dinler Kanunu'ndaki değişiklikler, Müslümanların haklarına bir kısıtlama getirmeden kabul edilmiştir.

Sonuç olarak 2019 itibariyle parlamentonun kabul ettiği değişiklikler sonucu Başmüftülük kurumuna, devlet bütçesinden yaklaşık 6 milyon leva yardım verilmeye başlanmıştır ${ }^{85}$. Ancak aynı yıl itibarıyla Başmüftülüğün devlete 8 milyon leva (4 milyon avro) vergi borcu birikmiştir ${ }^{86}$. Yani devletin yapacağı yardım, aslında kurumun devlete olan toplam birikmiş borcunu ödemeye yetmemektedir. Bunun üzerine bütün dinlerin kamuya olan borçlarının affedilmesine yönelik Dinler Kanunu'nun tekrar düzenlenmesini öneren GERB ve HÖH, kamuoyu tepkisinden dolayı geri adım atmış ve Başmüftülüğe ait borçların ödenmesinin on yıllık bir süreye yayılmasına yetkili merciler tarafından karar verilmiştir ${ }^{87}$.

\subsection{Vakıf Mallarının İadesi Sorunu}

Vakıflar, Osmanlı sonrası dönemde Balkanlardaki Müslüman grupların sosyo-ekonomik ve kültürel hayatında çok önemlidir. Çünkü vakıf mallarından elde edilen gelir sonucu dinî ve hayır kurum ile kuruluşlarının çalışmasında ve bu grupların özerlik statülerinde hayati önem arz etmektedir. Diğer bir ifadeyle vakıflar, o azınlığın kültürel varlığına katkı sunmanın yanında ekonomik olarak da tarihî varlığını sürdürmesinde önemlidir.

83 "Dinler Kanunu ile İlgili Resmî Bildiri”, 18 Mayıs 2018 (Çevrimiçi), Bulgaristan Başmüftülüğü, http://www. grandmufti.bg/bg/home/news-room/novini/6011-visshiyat-myusyulmanski-savet-s-pozitziya-otnosno-izmeneniyatav-zakona-za-veroizpovedaniyata.html, 8 Eylül 2020.

84 "Protest sreştu promenite v Zakona za veroizpovedaniyata v Sofiya [Sofya'da Dinler Kanunu değişikliklerine karş1 protesto]", Nova, 11 Kasım 2018 (Çevrimiçi), https://cutt.ly/rbDbs3U, 21 Ocak 2020.

85 “Devlet Bütçesi Yasası, 2020”, 2020 (Çevrimiçi), Maliye Bakanlığı, https://www.minfin.bg/bg/1408, 1 Kasım 2020.

86 BMDBA, $M \dot{I B}$.

87 "GERB se otkaza da oproshtava dılgovete [GERB borçları affetmekten vazgeçti]”, Kapital, 13 Mart 2019 (Çevrimiçi), https://www.capital.bg/politika_i_ikonomika/bulgaria/2019/03/13/3403981_gerb_se_otkaza_da_oproshtava_ dulgovete_na/, 13 Nisan 2020. 
Osmanlı mirası vakıf malları, bağımsızlık sonrası Bulgaristan'da farklı sorunlarla karşı karşıya kalmıştır. Bulgarların 93 Harbi’nden sonra devlet kurma çabaları doğrultusunda Türk İslam medeniyetinin izlerini taşıyan birçok eseri tahrip etmeleri üzerine Bulgaristan'da kalan vakıf eserlerinin korunması, iki devlet arasında belirli dönemlerde gündeme gelmiştir. Ayastefanos ile Berlin antlaşmalarında dile getirilen vakıf emlakının durumu, 1909 ve 1913 ’te Bulgaristan ile Osmanlı arasında imzalanan antlaşmalarla düzenlenmeye çalışılmıştır ${ }^{88}$.

Osmanlı döneminden kalan vakıf mallarının varisi, doğal olarak ülkede faaliyet gösteren Müslümanların dinî teşkilatı Başmüftülük olmuştur. Okullar, sosyal hizmet binalar1, cami ve binlerce dönüm tarım arazilerinden ibaret vakıf malları, farklı iktidarlar ve rejimler tarafından istimlak edilmiş; kalan eserlerin birçoğunun da vakfiyeleri ve tapuları imha edilmiştir. 1944'ten sonra komünist iktidarlar, vakıf mallarını Başmüftülüğün elinden alarak devletleştirmişlerdir. Başmüftülüğün tespitlerine göre yıllar içinde yıkımlara ve tahribatlara rağmen Bulgaristan'da 3.000'den fazla vakıf malı (cami, okul, işhanı ve tarım arazisi) bulunmaktadır. Ancak birçoğunun tapuları ve arşivlerdeki kayıtları yok edilmiştir. Komünist rejim döneminde Müslümanlara ait vakıf mallarının tapuları ve vakfiyeleri ile dinî eserler ve Türkçe kitaplar, evlerden ve camilerden toplanıp çoğunlukla imha edilmiştir. Böylece ileride de ele alınacağı üzere gayrimenkullerin iadesine ilişkin yasaların kabul edilmesinden sonra Başmüftülüğün mahkemelere sunabileceği çok fazla delil kalmamıştır ${ }^{89}$.

1989'dan sonra kabul edilen "Sahiplerine İade Yasası" kapsamında ülkedeki farklı dinî topluluklara ait devletleştirilmiş mülkiyet ve gayrimenkullerin, tapu veya geçerli sahiplik belgesi ibraz etmeleri durumunda kendilerine iade edilmesinin önü açılmıştır ${ }^{90}$. Böylece tüm dinler, gayrimenkullerinin tamamına yakınını geri alabilmiştir. Başmüftülük de bu uygulama kapsamında bazı Müslüman vakıf mallarını geri almış olsa da büyük bir kısmını, çeşitli engellerle karşılaşmış olmasından dolayı alamamıştır. 1990 sonrasında ilgili mevzuatlar, vakıf mallarının Müslümanlara ait olduğunu teyit etmelerine rağmen vakıf mallarının iadesi ile sorunlar, Bulgaristan'ın 2007'de AB üyesi olmasindan bu yana devam etmektedir.

88 İsmail Cambazov, Bulgaristan'da Başmüftülük Tarihi..., s. 378.

$89 B M D B A, V B$. Bulgaristan'daki vakıf malları hakkında detaylı bir araştırma ve 290 vakfiye metni için bkz. Halit Eren-Önder Bayır-Mustafa Oğuz-Zekai Mete, Balkanlar'da Osmanlı Vakıfları, Vakfiyeler: Bulgaristan, İstanbul, IRCICA, 2012.

90 “Gayrimenkullerin Geri İadesi Yasası, 1992”, 1992 (Çevrimiçi), Lex.bg, https://www.lex.bg/laws/ldoc/2132811266, 21 Temmuz 2020. 
Vakıf mallarının iadesi ile ilgili olarak Başmüftülüğün karşılaştığı temel sorunlar şunlardır: Tapu ve gerekli belgelerin arşivlerde bulunamaması (delil eksikliği), geri iade şartlarının devlet kurumları ve yerel yönetimler tarafından sürekli değiştirilmesi ve bu süreçte zorluk çıkarmaları, Başmüftülügüün kurultay kararlarını ve seçilen yönetimlerini tescil ettiremediği dönemlerde oluşan boşluklardan yararlanan Gencev başta olmak üzere bazı art niyetli kişilerin vakıf mallarını sahte belgelerle satması veya kendi çıkarları yönünde kullanmış olmaları, birçok vakıf malının "Arazi ve Yerleşim Yerleri Düzenlemesi Yasası" gereğince karşılı̆̆ı verilmeden istimlak edilmesi, yakın geçmişe kadar yürürlükte olan bazı yasalar gereğince bir vakıf malının geri iadesi için hukuki sürecin başlatılması adına iddia sahibinin mülkiyet değerinin $\% 4$ 'ünü ödemek zorunda kalması, vd. ${ }^{91}$ Özellikle bahse konu son madde kapsamında Başmüftülük, maddi yetersizlikler sebebiyle birçok paha biçilemez vakıf mülkiyetinin \%4 değerini ödeyememesinden dolayı dava başlatamamıştır ${ }^{92}$.

1990 sonrasında özellikle AB üyelik sürecinin de etkisiyle Başmüftülük -yukarıda da ifade edildiği- üzere elinde bulundurduğu ve arşivlerde korunabilmiş belgelerle Müslümanlara ait bazı vakıf mallarını geri alabilmiştir. Fakat diğer birçok vakıf eseri hakkında hukuki süreç başlatılmış olmasına karşın çeşitli teknik ve bürokratik engellerle karşılaşmıştır. 2003 'te yürürlüğe giren Dinler Yasası, 1991'deki yasanın vakıf mallarının geri alma süresi için öngördüğü on yıllık süreyi, 2013'e kadar on yıl daha uzatmıştır. Ancak bu süre zarfında vakıf mallarının geri kazanılması bir yana, davaların birçoğu delil eksikliği ve diğer sebeplerden dolayı mahkeme salonlarında kaybedilmiştir. Bunun üzerine Başmüftülük, iade süresinin uzatılması için siyasi partilerle görüşmüş ve Dinler Kanunu'nda değişiklikler yapılması talebinde bulunmuştur. HÖH milletvekilleri, 16 Temmuz 2013 tarihinde tüm dinlerin mülkiyetlerinin geri iadesi konusunda zaman aş1mının kaldırılmasını teklif etmişse de mecliste kabul edilmemiştir ${ }^{93}$. Bu on yıllık süreçte kurumun Müslümanlara ait vakıf mallarının iadesine yönelik faal olamamasının başlıca sebebi, daha önce ifade edildiği üzere 2003-2011 arasında mahkemelerin dinî liderliği sürüncemede bırakmış olmasıdır.

91 2014'teki düzenlemeyle yasadaki bu madde iptal edilmiştir.

$92 B M D B A, V B$.

93 "Dinler Kanunu Değişikliği Önergesi, no. 354-01-40”, 16 Temmuz 2013 (Çevrimiçi), Bulgaristan Parlamentosu, https://www.parliament.bg/bg/bills/ID/14489, 21 Aralık 2020. 
2013’te, sürecin bitimine yakın Başmüftülüğün mahkemeye Osmanlı döneminden kalan vakıfların mirasçısı sıfatıyla başvuru yaparak veraset davaları başlatması, bazı aşırı milliyetçi ve İslam karşıtı siyasi çevrelerin tepkisini çekmiştir ${ }^{94}$. Bu minvalde bazı yerel ve ulusal medya organları, Başmüftülüğe karşı karalama kampanyası başlatarak "Fırtına geliyor: Müftülük Bulgaristan’ın \%10'una el koyuyor"95 ve "Osmanlı İmparatorluğu'na Dönüyoruz"96 gibi kışkırtıcı başlıklar atmışlardır. Bazı belediye yönetimleri de iadeye karşı çıkıp medyayı ve yerel halkı örgütleyerek protestolar düzenlemişlerdir" ${ }^{97}$. Bazı belediye başkanları, demeçlerinde "Başmüftülüğ̈̈̈n camisi yok, ama provokasyon yapıyor. Davalarda camilere ilişkin hiçbir tapu veya belge sunamadılar" açıklamasına yer verirken ${ }^{98}$ Dupnista, Karlıova ve Küstendil gibi kasabaların belediye başkanları, aşırı milliyetçilerin de desteğiyle mahkemenin Başmüftülük lehine karar vermesi durumunda sivil itaatsizlik başlatacaklarını bildirmişlerdir ${ }^{99}$. Nitekim bir yıl sonra Filibe'deki vakıf mallarının iadesine ilişkin başlatılan davanın görüldüğü tarihte, şehir merkezinde aşırı milliyetçi grupların ve futbol taraftarlarının katıldığı protestolar sırasında, Birinci Murat Hüdavendigar Camii'ne taşlar ve patlayıcılarla saldırılırken caminin camları ve kapısına zarar verilmiştir ${ }^{100}$.

$\mathrm{Bu}$ protestolar, camilerin aidiyeti ile ilgili bazı tartışmaları da beraberinde getirmiştir. Milliyetçi partiler ve medya organları, 2012'den sonra yeniden başlatılan davalardan dolayı Başmüftülüğü devletin mülkiyetini gasp etmeye çalışan bir kurum olarak göstermeye çalışmışlardır. Başmüftülüğün davaları yenilediği on belediyenin başkanları, bir araya gelip belediyelerinde barış ve huzurun hâkim olması adına kamu mallarının

94 'Ekşın v Plovdiv: nad 1000 futbolni fenove hvırlyat bombi i blokirat ulitsi [Plovdiv'de Aksiyon: 1000'den fazla futbol taraftarı bomba atıyor ve sokakları kapatıyor]”, News.bg, 7 Şubat 2014 (Çevrimiçi), https://news.bg/bulgaria/ekshan-vplovdiv-nad-1000-futbolni-fenove-hvarlyat-bombi-i-blokirat-ulitsi.html, 25 Mart 2020.

95 "Kmet na Karlovo: Zadava se burya - muftiystvoto prevzema 10\% ot Bılgaria [Karlıva Belediye Başkanı: Fırtına geliyor - Müftülük Bulgaristan'ın \%10'una el koyuyor]”, Dimitrovgrad Bgvesti, 5 Aralık 2013 (Çevrimiçi), https:// www.dimitrovgrad.bgvesti.net/news/144618/kmett-na-karlovo-zadava-se-burya-myuftiystvoto-prevzema-10-otblgariya, 25 Mart 2020.

96 "Vrıştat ni v Osmanskata İmperiya [Osmanlı İmparatorluğu dönemine döndürülüyoruz]”, Duma, 27 Eylül 2013 (Çevrimiçi), https://duma.bg/vrashtat-ni-v-osmanskata-imperiya-n63361, 20 Mayıs 2020.

97 “Ataka Dupnitsa gotvi nepodçinenie, ako vırnat djamiata na muftiystvoto [Eğer cami müftülüğe verilirse ATAKA’nın Dupnitsa teşkilatı itaatsizlik yapacak]", Darik News, 28 Şubat 2013 (Çevrimiçi), https://dariknews.bg/regioni/ kiustendil/ataka-dupnica-gotvi-nepodchinenie-ako-vyrnat-dzhamiqta-na-myuftijstvoto-1048038, 22 Mart 2020.

98 Desislava Lübomirova, "Myuftistvoto niama djamii, no ni predizvikva [Müftülüğün camisi yok, fakat bize meydan okuyor]”, Actualno.com, 22 Nisan 2015 (Çevrimiçi), https://www.actualno.com/actualno/muftijstvoto-njama-djamiino-ni-predizvikva-news_469021.html, 2 Aralık 2020.

99 "Karlovtsi plaşat s grajdansko nepodçinenie [Karlıvalılar sivil itaatsizlik ile tehdit ediyor]", Standart, 15 Kasım 2013 (Çevrimiçi), https://www.standartnews.com/lifestyle-lyubopitno/karlovtsi_plashat_s_grazhdansko_ nepodchinenie-214105.html, 22 Mart 2020.

100 “Ultrasi Troşat Djamiata v Plovdiv [Aşırı milliyetçiler Filibe Camii’ne saldırdı]”, Webcafe, 14 Şubat 2014 (Çevrimiçi), https://webcafe.bg/newscafe/1030750469-ultrasi-troshat-dzhamiyata-v-plovdiv.html, 31 Mart 2020. 
mahkeme kararıyla veya Dinler Kanunu değişiklikleriyle müftülüğe iadesine izin verilmemesi gerektiği yönünde açıklamalarda bulunmuşlardır ${ }^{101}$. Bu bağlamda Karlıva Belediye Başkanı Emil Kabaivanov, basına "Müftülüğün geri almak istediği camileri Osmanlı işgalcileri bu topraklara Bulgarlara sormadan inşa etmiştir, üstelik çoğu kiliselerin üzerine yapılmıştır, bu camileri almaya kimsenin hakkı yoktur..." yönünde açıklamalarda bulunmuştur ${ }^{102}$. Davaların görüldüğü şehirlerde yapılan protestolar sırasında "Camiler sizin olabilir, ancak bu camiler kiliselerimizin temelleri üzerine inşa edilmiştir" sloganları atılarak devlet kurumlarına baskı yapılmaya çalışılmıştır. Dahası Karlıva kasabasındaki Kurşunlu Camii gibi bazı ibadethanelerde, temellerinde farklı dönemlere ait yapılar arama bahanesiyle arkeolojik kazılar başlatılmıştır ${ }^{103}$.

Nitekim 2009'da Eski Zağra'daki (Stara Zagora) Hamzabey Camii, Müslüman toplumunun ve Başmüftülüğün tepkilerine rağmen dinler müzesine çevrilmiştir. $A B$ ve Bulgar kurumlarının ortak finansörlügünde gerçekleşen müze projesi ile ilgili Başmüftülük, dönemin Avrupa Komisyonu Başkanı'na resmî bir yazı göndermesine rağmen olumlu cevap alamamıştır. Konsey cevaben; mülkiyetin Bulgar devleti ve Kültür Bakanlığı'na ait olduğunu, yapılan kazılar sırasında daha farklı dönemlere ve dinlere ait yapıların bulunduğunu ve bu sebeple de müzenin farklı dinler arasındaki etkileşimi teşvik edeceğini, halihazırda AB'de bu meseleyi çözebilecek herhangi bir yasanın bulunmadığını bildirip Başmüftülüğe gerekli Bulgar makamlarıyla görüşerek meseleyi çözmesini önermiştir ${ }^{104}$. Benzer şekilde Kırcaali kasabasında 1920'lerde Müslüman toplumunun bağışlarıyla inşa edilen medrese, günümüzde belediyeye ait bir müze olarak kullanılmaktadır. Ayrıca Sofya'da, yapımına 1451'de başlanmış olup günümüzde arkeoloji müzesi olarak kullanılan Mahmut Paşa Camii ile yine aynı şehirdeki 1548 tarihli bir Mimar Sinan eseri olup 1900’lerin başından beri kilise olarak işlev gören Kara Camii bunlara benzer örneklerdendir ${ }^{105}$.

101 Maya Yordanova, "Kmetove se obedinyavat sreştu pretentsiite na müftiystvoto [Belediye başkanları müftülüğün taleplerine karşı birleşiyor]", Novini.bg, 30 Kasım 2013 (Çevrimiçi), https://novini.bg/bylgariya/obshtestvo/168654, 30 Nisan 2020.

102 "Kmet na Karlovo: "Zadava se burya - muftiystvoto prevzema 10\% ot Bılgaria [Karlıva Belediye Başkanı: Fırtına geliyor - Müftülük Bulgaristan'ın 10\%'una el koyuyor]”, Dimitrovgrad Bgvesti, 5 Aralık 2013 (Çevrimiçi), https:// www.dimitrovgrad.bgvesti.net/news/144618/kmett-na-karlovo-zadava-se-burya-myuftiystvoto-prevzema-10-otblgariya, 25 Mart 2020.

103 Leyla Çauşeva, "Nesekvaştite opiti za promyana - prednaznaçenieto na Kurshun djamiya v Karlovo [Karlıova'da Kurşun Camii’nin statüsünü sonu gelmeyen değiştirme teşebbüsleri]”, 19 Ekim 2018 (Çevrimiçi), Bulgaristan Başmüftülüğü, http:/www.grandmufti.bg/bg/home/news-room/novini/6677-nesekvashtite-opiti-za-promyana-prednaznachenieto-nakurshum-dzhamiya-v-karlovo.html, 20 Ekim 2020.

$104 B M D B A, D I B$.

$105 B M D B A, V B$. 
Vakıf mallarının iadesine ilişkin Başmüftülüğün başlattığı hukuki süreçler analiz edildiğinde, Bulgar devletinin eski dönemlere ait tapu ve resmî belgelerine dayandırılmalarına rağmen Bulgar yargısı bu resmî belgelerin geçerliliğinden sürekli şüphe duymuştur. Ayrıca tüm hukuki süreçlerin meclisin onayladığı yasalar dâhilinde yürütülmesine rağmen olumlu neticeler alınamamıştır. Bazı durumlarda yargının siyasi partilerin ve/veya milliyetçi grupların baskılarından etkilenip kararlar aldığg da görülmektedir ${ }^{106}$.

Başmüftülük, vakıflar konusunda bir taraftan bürokratik zorluklar ve milliyetçilerin baskılarıyla diğer taraftan totaliter rejimin başmüftüsü Gencev'in yolsuzluklarıyla uğraşmak zorunda kalmıştır. Bu noktada 2003'te yürürlüğe giren Dinler Yasası'ndan istifade ederek kurduğu “Bulgaristan'da Müslüman Sünni-Hanefi Diyaneti”ni temsilen Gencev, kendisinin ve temsil ettiği dinî kuruluşun 1949 öncesi Müslüman kurumların varisi olduğu iddiasıyla devreye girmiş ve mahkemelere başvurmuştur. $\mathrm{Bu}$ sebeple Bulgaristan yargısı, vakıflarla ilgili davalarda hukuki süreci durdurarak gerçek varislerin belirlenmesini istemiştir ${ }^{107}$. Nitekim Bulgaristan yasalarının, bir mülkün birden fazla mirasçısının bulunması durumunda önce mirasçıların kendi aralarında anlaşmasını istemesinden dolayı davalar uzun ve karmaşık bir hal almıştır ${ }^{108}$. Böylece vakıfların iadesine ilişkin yapılan girişimlere Gencev'in de Müslümanların “temsilcisi” olarak müdahil olması, yasal süreçleri çıkmaza sokmuştur. 2003 sonrasında Gencev'in, birçok vakıf malını mahkemenin kendisine verdiği dinî kurumun temsilcisi resmî sıfatıyla kendi lehine kiraya verdiği veya satışa çıkardığı ayrıca Başmüftülüğün banka hesaplarından 1 milyon avroya yakın miktarı farklı hesaplara aktardığı bilinmektedir ${ }^{109}$. Hukuksal boşluklardan istifade eden Gencev ve ekibi, Müslümanların vakıf mallarını şahsi menfaatleri doğrultusunda kullanmıştır. Böylece Başmüftülüğün yönetiminin tescil sorunu, vakıf malları meselesini de olumsuz etkilemiştir. Başmüftülük yönetimi, 2008-2011 yıllarında Gencev ve ekibi hakkında onlarca suç duyurusunda bulunmuş, yapılan suçlar ve yolsuzluklar dosya halinde Başsavcılığa ve yetkili kurumlara sunulup gereğinin yapılacağına dair taahhütler alınmasına rağmen ilgili soruşturmalar ve açılan davalar sonuçsuz kalmıştır ${ }^{110}$.

106 Murat Pingov ile yapılan 17 Şubat 2020 tarihli mülakat.

$107 B M D B A, V B$.

108 İrina Georgieva, "Sofiyskiya apelativen sıd otloji deloto za vakıfskite imoti [Sofya İstinaf Mahkemesi vakıf malları davasını erteledi]”, Bulgaria On Air, 24 Ekim 2014 (Çevrimiçi), https://www.bgonair.bg/bulgaria/2014-10-24/otlagatdeloto-za-kurshum-dzhamiya, 11 Ocak 2020.

109 BMDBA, $M D B$, Sofya Bölge Mahkemesi, Dava Kararı no. 2402/2008.

110 Mustafa Hacı ile yapılan 19 Kasım 2019 tarihli mülakat. 
Bugün Osmanlı döneminden kalan vakıf mallarının bir kısmı, Bulgaristan’ın ulusal kültür mirası listesinde, dolayısıyla da devletin ve belediyelerin mülkiyetindedir. Buna rağmen bu listede yer alan camilerin bazıları yıkılmaya yüz tutmuştur. Ülkenin sürekli ekonomik sorunları ele alındığında Kültür Bakanlığı ve belediyelerin bu tarihi mirasların tadilatları için para ayıramıyor olması anlaşılabilir. Fakat bu eserlerin içlerinde veya etraflarında Osmanlı öncesi dönemle ilgili kalıntılar bulmak için yapılan arkeolojik kazıları teşvik etmeleri ${ }^{111}$, Osmanlı kültürel mirasının korunması ve geleceğe ulaştırılması adına düşündürücüdür.

Restorasyon gerektiren tarihi eserlerin Türkiye'nin yardımıyla restore edilmesi, son 30 yıldır iki ülke arasında yapılan görüşmelerin birçoğunda gündeme gelmiştir. Yine 2013 ’te Bulgaristan'a resmî ziyarette bulunan dönemin Türkiye Cumhuriyeti Başbakan Yardımcısı Bekir Bozdağ, vakıf mallarının durumunu Bulgaristan'daki mevkidaşlarıyla ve kültür bakanıyla görüşmüş; Osmanlı dönemine ait tarihi ve kültürel mirasta gerekli tadilatın Türkiye'nin yardımı ile yapılmasını önermiştir ${ }^{12}$. Konuya ilişkin Kültür Bakanı Petır Stoyanoviç'in basına yaptığı açıklamalar daha farklı olmuştur. Stoyanoviç, vakıf mülkiyeti sorununun 1909' da Osmanlı Devleti ile imzalanan antlaşmayla çözülmüş olduğunu, kullanılmayan vakıfların Bulgaristan devletine kaldığını; ancak Türkiye'nin İslam mimarisi anıtlarının onarılması konusunda yardım teklifine olumlu baktığını, UNESCO ile çalışmalar örneğinde yardım kabul edilebileceğini açıklamıştır ${ }^{113}$. Bu eksende farklı hayırseverlerin desteği ile bazı camilerin onarılmasına başlanmıştır; fakat süreç ağır yürümekte ve onarım bittikten sonra camilerin müzeye dönüştürülmesi söz konusu olabilmektedir. Yunanistan ile Bulgaristan'1n da Türkiye'deki kurum ve kuruluşların Osmanlı eserlerinin korunmasına yönelik hiçbir talebe olumlu cevap vermeyen iki Balkan ülkesi olması, bu eserlerin gelecekteki akıbetleri adına soru işaretlerini de beraberinde getirmektedir.

Demokrasi döneminin ilk yıllarında vakıf mallarının iadesi meselesine ilişkin umut verici yasal çözümler getirilmiş olsa da durumun Bulgaristan'ın AB üyeliğinden bu yana devam ediyor olmasının bu çalışma adına önemi şudur: AB'nin normatif gücü, bazı vakıf mallarının iadesinde etkili olurken diğer birçok vakıf malı için etkisiz kalmıştır. Bunun yanında, 2007'de AB üyesi olmuş Bulgaristan'ın son 13 yıldır iadelerle ilgili

$111 B M D B A, M D B$.

112 "Başbakan Yardımcısı Bekir Bozdağ: 'Bulgaristan'daki Osmanlı eserlerine sahip çıkıyoruz’”, Kırcaali Haber, 9 Ağustos 2013 (Çevrimiçi), https://www.kircaalihaber.com/?pid=3\&id_news=11308, 2 Şubat 2020.

113 "Vıprosit s Osmanskite imoti e ureden - uveri kulturniat ministır [Kültür Bakanı: Osmanlı mülkiyeti ile mesele halledildi]", Darik News, 12 Ağustos 2013 (Çevrimiçi), https://dariknews.bg/novini/bylgariia/vyprosyt-s-osmanskiteimoti-e-ureden-uveri-kulturniqt-ministyr-1128638, 1 Aralık 2020. 
izlediği politikalar, post-totaliter dönemde azınlık haklarının iadeleriyle ilgili "iyi niyet"in bir kez daha sorgulanmasina sebebiyet vermektedir.

\section{4. İbadethane Meselesi}

2020 itibarıyla Bulgaristan'da halihazırda yaklaşık 1.738 cami ve mescit bulunmaktadır. Bunların 1.523 tanesi faal durumdayken $215^{\prime}$ 'i ise imam ve cemaat yetersizliğinden dolayı kapalıdır. Cami ve mescitlerin yaklaşık 370'i 1989'dan sonra inşa edilmiş$\operatorname{tir}^{114}$. Günümüz itibarıyla Bulgaristan'da büyük şehirlerin çoğunda faaliyet gösteren Osmanlı dönemine ait genellikle birer cami bulunmaktadır. Ancak 1990’ların başından itibaren Müslümanların dinî hürriyetlerine kavuşmasından dolayı cami cemaatinin artması, vatandaşların önemli bir kısmının iç göç sonucu büyük şehirlere yerleşmesi ve Müslüman ülkelerden gelen göçmenlerin de buraları tercih etmeleri sebebiyle şehirlerdeki camilerin kapasitesi zaman içerisinde yetersiz kalmıştır. Demokrasiye geçiş döneminde birçok yerleşim yerine yeni camiler inşa edilmiş olsa da Sofya ve Eski Zağra gibi büyük şehirlere ihtiyaç olmasına rağmen ikinci bir cami yapılmasına izin verilmemiş hatta Burgaz gibi camisi bulunmaya şehirlere ilki dahi inşa edilememiştir. Örneğin Sofya'da, sadece 16. yüzyılda inşa edilmiş 600 kişi kapasiteli Banyabaşı Camii olduğundan cuma ve bayram namazlarını, mabedin önündeki kaldırımda ve sokakta kılanların sayısı oldukça fazladır. 2011'de ATAKA Partisi sempatizanlarının, bir cuma günü Müslümanlara provokasyon yapmak için kasten “sokakta namaz kılıyorlar” gerekçesiyle taş ve sopalarla saldırıp cezasız kalmaları, bu sorunun açık bir örneğidir. İbadethane eksikliği ile ilgili azınlıkların yaşadıkları sorunların, en son Mayıs 2020 tarihli bir Avrupa Konseyi metninde altı çizilmiş ve bu yönde Bulgaristan'ın, azınlıklar ile iş birliği içinde gerekli adımları ivedilikle atması önerilmiştir ${ }^{115}$.

Başmüftülüğün, ülkedeki Müslüman din adamı ve ilahiyatçı akademisyen ihtiyacını gidermek adına 2001'de idari, kültür ve eğitim merkezi kurma amacıyla Sofya'da satın aldığ1 27 dönümlük arazinin inşaatı belediyenin izni olmadığından dolayı hâlâ başlayamamıştır. 2008'de yılında bir takım milliyetçi gruplar, Başmüftülüğün büyükşehir belediyesi ile söz konusu proje hakkında yürüttüğü görüşmeleri protesto etmiş, kamuoyuna "Müftülük Sofya'da 5 katll cami inşa edecek"”116 şeklinde söylemlerde bulunup negatif

$114 B M D B A, V B$.

115 "Fourth Opinion on Bulgaria, ACFC/OP/IV(2020)001Final (Advisory Committee On The Framework Convention For The Protection Of National Minorities)", 26 Mayıs 2020 (Çevrimiçi), s. 28, https://rm.coe.int/4th-op-bulgariaen/16809eb483, 22 Ekim 2020.

116 Zlatko Jelev, "Proektıt gotov! 5-etajna djamia v Sofia” [Proje hazır! Sofya'da 5 katlı cami]”, 26 Kasım 2008 (Çevrimiçi), Dnes.bg, https://www.dnes.bg/obshtestvo/2008/11/26/proektyt-gotov-5-etajna-djamiia-v-sofiia.61564,12, 20 Şubat 2020 . 
alg1 oluşturmaya çalışmışlardır. Sofya Büyükşehir Belediyesi de inşaat izni konusunda çelişkili gerekçeler sunmuştur. Örneğin önce projede yer alan küçük bir minare, minarenin iptal edilmesinden sonra ise milliyetçi partilerin baskıları bahane edilmiş; bahane edilecek bir şey kalmadığında, belediyenin baş mimarı ile aylar boyunca görüşme randevusu alınamamıştır ${ }^{117}$. Böylelikle AB üyeliğinin de Müslümanların en temel ihtiyaçlarından olan camilerde toplu ibadet etme özgürlüğüne önemli katkı sağlamadığı görülmektedir.

\section{Sonuç}

Bu çalışmada 1989'dan sonra demokrasiye geçiş dönemiyle başlayıp Bulgaristan'ın $\mathrm{AB}$ üyeliği sonrası dönemde de devam eden ülkedeki Müslümanların din hürriyeti bağlamında birkaç temel konu ele alınmıştır. Soğuk Savaş'ın sona ermesi ve demokrasiye geçişten günümüze kadarki süreçte Bulgaristan, gerçekleştirmiş olduğu reformlarla azınlık hakları konusunda önemli yol kat etmiştir. Ancak gerek ulusal mevzuat gerekse uluslararası sözleşmelerle azınlık hakları garanti altına alınmış olmasına rağmen uygulamada sorunlar yaşanmaya devam etmiştir.

Komünist rejimin sona ermesinde önemli rol oynayan Müslüman azınlık, demokrasi döneminin ilk yıllarında dinî hürriyetlerine ve dinî kuruluşlarına tam manasıyla sahip çıkamamıştır. Rejim sonrası oluşan yeni şartlar altında topluma yönelik hizmetlerini ve faaliyetlerini arttırma fırsatı bulan Bulgaristan, Başmüftülük ile siyasi, hukuki ve bürokratik engelleri aşmakta uzun süre ciddi sorunlar yaşamışlardır. Bulgaristan Müslümanlarının dinî özgürlüklerine ilişkin en ciddi hak ihlali, şüphesiz dinî kurumlarına yönelik olmuştur. Etnik aidiyeti ne olursa olsun Müslümanları aynı çatı altında birleştiren Başmüftülügüun çeşitli yöntemlerle zayıflatılmaya ve yıpratılmaya çalışılması, kontrol altında tutularak sürekli kriz halinde bırakılması, kurumun temsil ettiği topluluğun ve bireylerin temel hak-özgürlüklerine yönelik bir müdahaledir. Zira Müslümanlar, kendilerini temsil eden Başmüftülük kurumuna demokratik yollarla yapılan seçimler vasıtasıyla Müslümanların da mülkiyeti sayılan vakıf mallarının yönetilmesi ve dinî hizmet yetkisi vermektedir.

AB'ye tam üyelik hazırlıkları aşamasında 2002'de kabul edilen yeni Dinler Kanunu, bir taraftan ülkedeki Müslüman toplumunun dinî özgürlüklerine yönelik olumlu katkılar sağlarken diğer yandan Müslümanları eski dönemlerin etkisi altında devam eden bazı olumsuzluklarla karşı karşıya bırakmıştır. Bu durumda Bulgaristan Müslümanlarının 
neredeyse tamamı, kendi acı tecrübelerinden mütevellit ülkenin demokratikleşmesi ile ilgili süreci yakından takip etmiştir. Bir yandan Avrupalılaşma yönünde attığı adımları desteklerken diğer yandan eski rejimin baskıcı azınlık politikalarının yansımalarını kayg1yla izlemiştir.

$\mathrm{Bu}$ çerçevede demokrasiye geçiş sürecinin başından itibaren AB üyeliği sonrası döneme kadar dinî kurumların yeniden yapılandırılması ve Başmüftülüğün hukuki statüsüne ilişkin bazı sorunların ülkedeki siyasi konjonktüre ve iktidarlara bağlı olarak değişim göstermesi, Müslümanların dinî hakları ile ilgili sorunların siyasi bir kaynağının da olduğunun işaretidir. Siyasi çevrelerin uzun y1llar kurumun iç işleri ve işleyişi üzerinde etkili olmasının Başmüftülük kurumuna her zaman olumlu yansımaları olmadığını, geçmişte yaşanan olaylar bizlere göstermektedir. Bu açıdan son yıllarda Başmüftülüğün, siyasi partilerle yakınlığını en aza indirmiş olması oldukça manidardır. Böylelikle Başmüftülüğün siyaseten daha bağımsı hareket etme olanağına sahip olduğu gözlemlenmektedir.

Başmüftülükle ilgili sorunların Bulgaristan'ın AB üyeliğinden sonraki süreçte de uzun süre devam etmesi, adaylık sürecinde karşılanmış olması gereken Kopenhag Kriterleri'nin 2007 sonrası ihlal edildiği anlamına gelmektedir. Bu noktada başta Başmüftülük kurumu olmak üzere ülkedeki Müslüman STK'larının, gerek Müslümanların dinî kurumlarına yapılan müdahaleleri gerekse vakıf mallarının iadesi ve ibadethane ihtiyaçlarının giderilmesi ile ilgili sorunları AB, Avrupa Konseyi ve AGITT gibi uluslararası platformlarda sürekli olarak bildirmelerine rağmen pratikte tatmin edici sonuçların hâlâ alınamamış olması; evrensel değer ve normların savunulması ile ilgili karmaşıklığının bir göstergesi olduğu kadar bu çalışmanın teorik çerçevesi bağlamında normatif teoriden faydalanmanın, konunun analiz edilmesi adına ne derece önemli ve yerinde olduğunun da bir göstergesidir.

2019'da Dinler Kanunu'nda yapılan değişikliklerle Başmüftülük kurumunun devlet ile ilişkileri farklı bir evreye girmiştir. Yıllık bütçesinin neredeyse yarısını oluşturan devlet desteği ile Başmüftülük, artık bir bütçe kuruluşu statüsünü almıştır. Diğer taraftan devletin bütçesinden yardım sağlanmaya başlaması, halkın seçtiği müftülerin yönetimindeki Başmüftülüğün devlet katında artık daha fazla önemsendiği anlamına gelebilir. Fakat Başmüftülük ile devlet ilişkilerine tarihî perspektiften bakıldı̆̆ında, kanun değişiklikleriyle sağlanan bu yardım, Başmüftülük kurumunun iç işlerine müdahalenin başka bir yöntemi olarak da yorumlanabilir. Bu son düzenlemenin Müslümanlar ve Başmüftülük üzerindeki kısa ve orta vadeli yansımaları, 2021'de düzenlenecek olan 
Olağan Müslümanlar Kurultayı ve yine aynı yıl yapılacak genel seçimler ile nüfus sayımı sonrası dönemde daha net şekilde görülecektir.

Hakem Değerlendirmesi: Dıș bağımsız.

Çıkar Çatışması: Yazarlar çıkar çatışması bildirmemiştir.

Finansal Destek: Yazarlar bu çalışma için finansal destek almadığını beyan etmiştir.

Peer-review: Externally peer-reviewed.

Conflict of Interest: The authors have no conflict of interest to declare.

Grant Support: The authors declared that this study has received no financial support.

\section{KAYNAKÇA}

\section{Arşiv Belgeleri}

\subsection{Bulgaristan Müslümanlar Diyaneti Başmüftülü̆ğ̈̈ Arşivi $(B M D B A)^{118}$}

Dış İlişkiler Bölümü (DİB)

Mahkeme Davaları Bölümü (MDB), Sofya Bölge Mahkemesi, Dava Kararı no. 2402/2008.

Mali Işsler Bölümü (MIB)

Vakıflar Bölümü (VB)

\section{Resmî Yayınlar}

Başmüftülük Tüzüğ̈̈, Bulgaristan Müslümanlar Diyaneti, Sofya, 2016.

"Reşenie na Narodnoto sıbranie, Strategiya za natsionalna sigursnost [Ulusal Güvenlik

Stratejisi ve Meclisin Karar1]", Dırjaven vestnik [Resmî Gazete], no. 46, 22.04.1998, Sofya.

\section{Araştırma Eserler}

Ahmed, Vedat: "Bulgaristan Müslüman-Türk Azınlığı'nın Dinî Hakları ve Bulgaristan Müslümanları Başmüftülügü̈”, 100 Godini Glavno Muftiystvo-Yubileen Sbornik [100 Yll Müftülük: Jubile Derlemesi], ed. Vedat Ahmed, Sofya, Bulgaristan Müslümanları Başmüftülüğü, 2011, s. 80-101.

118 Bulgaristan Müslümanlar Diyaneti Başmüftülüğü Arşivi’ndeki araştırmalar, 6-31 Ocak 2020 tarihleri arasında sürdürülmüştür. Fakat arşivin 2020 itibarıyla düzenlenme aşamasında olması sebebiyle belgeler sınıflandırılmış olmasına karşın kataloglanıp sıra numarası verilmediği not edilmelidir. Bu sebeple çalışmada kullanılan bazı arşiv materyallerinde katalog veya sıra no belirtilmemiştir. 
Belgelerle Mustafa Kemal Atatürk ve Türk Bulgar Ilişkileri (1913-1938), der. Panto Kolev, Cengiz Hakov, Ogniyan Punev, Iliyana Paskova, Liliya Tsvetkova, ter. Elena Mirçeva, Ankara, Başbakanlık Devlet Arşivleri Genel Müdürlüğü, 2002.

Buchsenschutz, Ulrich: Maltsinstvenata politika v Bllgariya: Politikata na BKP kım evrei, romi, pomatsi i turtsi (1944-1989) [Bulgaristan'da Azınlık Politikalarl: Yahudilere, Çingenelere, Pomaklara ve Türklere yönelik BKP'nin Politikası (19441989)], Sofya, IMIR, 2000.

Bulgaristan'da Insan Haklarl, Temel Hak ve Hürriyetler, ed. Bülent Yıldırım, Edirne, Trakya Üniversitesi Yayınları, 2016.

Cambazov, İsmail: 100 Yll Başmüftülük - Tarihçe, Sofya, Bulgaristan Müslümanları Başmüftülüğü, 2011.

Cambazov, İsmail: Bulgaristan'da Başmüftülük Tarihi: 1944-2012, İkinci Kitap, Sofya, Bulgaristan Müslümanları Başmüftülüğü, 2013.

Crampton, Richard J.: A Concise History of Bulgaria, Cambridge, Cambridge University Press, 2006.

Crampton, Richard J.: Bulgaria, Oxford, Oxford University Press, 2007.

Dayığlu, Ali: “Muslim-Turkish Minority's Freedom of Religion and Conscience and the Problem of Head Muftiate in Bulgaria Between 1989 and 2011", Journal of Social Sciences, C.V, S.1, 2012, s. 2-33.

Dragostinova, Theodora: Between Two Motherlands: Nationality and Emigration among the Greeks of Bulgaria, 1900-1949, Ithaca and London, Cornell University Press, 2011.

Emeklier, Bilgehan: "Uluslararası İlişkiler Disiplininde Epistemolojik Paradigma Tartışmaları: Postpozitivist Kuramlar”, Bilge Strateji, C.3, S.4, 2011, s. 139-184.

Eminov, Ali: "Islam And Muslims in Bulgaria: A Brief History", Islamic Studies, Islam in the Balkans Özel Sayısı, C.36, S.2/3, Islamabad, Islamic Research Institute, International Islamic University, 1997, s. 209-241.

Eren, Halit-Bayır, Önder-Oğuz, Mustafa-Mete, Zekai: Balkanlar'da Osmanlı Vakıfları, Vakfiyeler: Bulgaristan, İstanbul, IRCICA, 2012.

Erskine, Toni: "Normative Theory", International Relations Theories: Dicipline and Diversity, eds. Tim Dunne, Milja Kurki, Steve Smith, Oxford, Oxford University Press, 2013, s. 36-57.

Evans, Graham-Newnham, Richard: The Penguin Dictionary of International Relations, London, Penguin, 1998.

Goldstein, Joshua S.-Pevehouse, Jon C.: Uluslararası İlişkiler, çev. Haluk Özdemir, Ankara, BB101 Yayınları, 2015. 
Hac1, Mustafa: "Demokratik Değişimlerden Sonra Başmüftülük”, Sofya Yüksek Íslam Enstitüsü Yıllı̆̆ı 2, Sofya, Yüksek İslam Enstitüsü, 2010, s. 5-20.

İsov, Mümin: "Bulgaristan Tarih Ders Kitaplarında Türk Azınlığın Yerine İlişkin Bazı Gözlemler”, Balkan Araştırma Enstitüsü Dergisi, C.III, S. 1, 2014, s. 37-51.

İvanov, Mihail: "Shtrihi ot Obraza na B1lgarskite Müsülmani-2016 [Bulgaristan Müslümanlarının Yüz Hatları-2016]", Müsülmanite v Bllgariya: Dinamika na Naglasite [Bulgaristan'da Müslümanlar: Eğilim Dinamikleri], ed. Evgeniya İvanova, Sofya, NBU, 2017, s. 7-12.

İvanova, Evgeniya: Religiyata kato prestıplenie: Bılgarskata islamska dırjava [Bir Suç Olarak Din: Bulgar İslam Devleti], Sofya, NBU, 2020.

Jelyazkova, Antonina: "Dırjavata, Myuftiyskata Institutsiya i Obştestvo v Bılgariya [Bulgaristan'da Devlet, Müftülük Kurumu ve Toplum]", 100 Godini Glavno Muftiystvo-Yubileen Sbornik [100 Yıl Müftülük: Jubile Derlemesi], ed. Vedat Ahmed, Sofya, Bulgaristan Müslümanları Başmüftülüğü, 2011, s. 35-42.

Kamil, İbrahim: Bulgaristan Türkleri ve Göçler, C.I, Ankara, Atatürk Araştırma Merkezi, 2018.

Kamusella, Tomasz: Ethnic Cleansing During The Cold War: The Forgotten 1989 Expulsion of Turks From Communist Bulgaria, London, NY, Routledge, 2020.

Kanev, Krassimir: "Law and Politics toward the Muslims in Bulgaria", Protecting the Human Rights of Minorities in Eastern Europe, eds. Peter G. Danchin, Elizabeth A. Cole, NY, Columbia University Press, 2002, s. 316-344.

Korkmaz, Nuri: “Comparing Bulgarian and Greek Policies for the Integration of Turkish/ Muslim Minorities: The Cold War Period", Bilig, C.90, 2019, s. 21-41.

Lütem, Ömer Engin: Türk-Bulgar İlişkileri 1983-1989, Cilt II (1986-1987), Ankara, Avrasya Stratejik Araştırmalar Merkezi (ASAM) Yayınları, 2006.

Muyhtar, Fatme: The Human Rights of Muslims in Bulgaria in Law and Politics since 1878, Sofia, Bulgarian Helsinki Committee, 2003.

Nazırska, Jorjeta: Bılgarskata Dırşava I Neynite Maltsinstva 1879-1885 [Bulgar Devleti ve Azınlıkları 1879-1885], Sofya, LIK, 1999.

Neuburger, Mary: The Orient Within: Muslim Minorities and the Negotiation of Nationhood in Modern Bulgaria, Ithaca, Cornell University Press, 2004.

Otfinoski, Steven: Nations in Transition: Bulgaria, 2nd ed., NY, Facts on File, 2004.

Özlem, Kader: “1925 Türkiye-Bulgaristan Dostluk Antlaşması'nın Bulgaristan Türklerinin Azınlık Hakları Bağlamında Analizi”, Prof. Dr. Mehmet Genç'e Armağan, ed. Kamuran Reçber, Barış Özdal, Zeynep Özgen, Bursa, Dora, 2016, s. 535-549. 
Riis, Carsten: Religion, Politics and Historiography in Bulgaria, NY, Columbia University Press, 2002.

Şimşir, Bilal: Bulgaristan Türkleri, 2. bs., Ankara, Bilgi Yayınevi, 2009.

Viotti, Paul R.-Kauppi, Mark V.: International Relations Theory, 5th ed., Boston, Longman (Pearson), 2012.

Yalımov, İbrahim: "Predizvikatelstvata Pred Muftiyskata Institutsia v İstoriçeski Rakurs

[Tarihî Planda Müftülük Kurumunun Önündeki Zorluklar]”, 100 Godini Glavno Muftiystvo: Yubileen Sbornik [100 Yıl Müftülük: Jubile Derlemesi], ed. Vedat Ahmed, Sofya, Bulgaristan Müslümanları Başmüftülüğü, 2011, s. 22-35.

Yalımov, İbrahim: Bulgaristan Türk Topluluğunun Etnokültürel ve Dinsel Kimliği, Sofya, Müslümanlar Diyaneti Başmüftülüğü, 2016.

Yalımov, İbrahim: İstoria na Turskata Obştnost v Bulgaria [Bulgaristan Türk Topluluğu Tarihi], Sofya, IMIR, 2002.

\section{Mülakatlar}

Ali Hüseyinoğlu tarafından Mustafa Hacı ile yapılan mülakat, Sofya, 19 Kasım 2019. Hayri Emin tarafindan Murat Pingov ile yapılan mülakat, Sofya, 17 Şubat 2020.

\section{Elektronik Kaynaklar}

“Ataka Dupnitsa gotvi nepodçinenie, ako virnat djamiata na muftiystvoto [Ĕger cami müftülüğe verilirse ATAKA'nın Dupnitsa teşkilatı itaatsizlik yapacak]”, Darik News, 28 Şubat 2013 (Çevrimiçi), https://dariknews.bg/regioni/kiustendil/ataka-dupnicagotvi-nepodchinenie-ako-vyrnat-dzhamiqta-na-myuftijstvoto-1048038, 22 Mart 2020.

“Başbakan Yardımcısı Bekir Bozdağ: Bulgaristan'daki Osmanlı eserlerine sahip çıkıyoruz", Kırcaali Haber, 9 Ağustos 2013 (Çevrimiçi), https://www.kircaalihaber. com/?pid=3\&id_news=11308, 2 Şubat 2020 .

“Devlet Bütçesi Yasas1, 2001”, 2001 (Çevrimiçi), Maliye Bakanlığı, https://www.minfin. bg/bg/264, 11 Eylül 2020.

“Devlet Bütçesi Yasas1, 2020”, 2020 (Çevrimiçi), Maliye Bakanlığı, https://www.minfin. bg/bg/1408, 1 Kasim 2020.

“Dinler Kanunu Değişikliği Önergesi, no. 354-01-40”, 16 Temmuz 2013 (Çevrimiçi), Bulgaristan Parlamentosu, https://www.parliament.bg/bg/bills/ID/14489, 22 Aralık 2020. “DinlerKanunuileİlgiliResmîBildiri”, 18Mayıs 2018(Çevrimiçi), BulgaristanBaşmüftülüğü, http://www.grandmufti.bg/bg/home/news-room/novini/6011-visshiyat-myusyulmanskisavet-s-pozitziya-otnosno-izmeneniyata-v-zakona-za-veroizpovedaniyata.html, 8 Eylül 2020. 
“Dinler Kanunu Önerileri, no. 854-01-34”, 4 Mayıs 2018 (Çevrimiçi), Bulgaristan Parlamentosu, https://www.parliament.bg/bg/bills, 13 Haziran 2020.

“Dinler Kanunu Tasarısı, no. 854-01-35”, 9 Mayıs 2018 (Çevrimiçi), Bulgaristan Parlamentosu, https://www.parliament.bg/bg/bills/ID/78070, 13 Haziran 2020.

“Dinler Kanunu, 2019”, 2019 (Çevrimiçi), Bulgaristan Cumhuriyeti Başbakanlığ 1 Din İşleri Müdürlüğü, http://veroizpovedania.government.bg/data/docs/1566950168484. pdf?fbclid=IwAR3LCwq4vTosf342g9sq5Bbvc_-uzvGr4sU3PbHwQFqnE1 tRbd1jzqofzY, 10 Ağustos 2020.

“Ekşın v Plovdiv: nad 1000 futbolni fenove hvırlyat bombi i blokirat ulitsi [Plovdiv’te Aksiyon: 1000'den fazla futbol taraftarı bomba atıyor ve sokakları kapatiyor]', News. bg, 7 Şubat 2014 (Çevrimiçi), https://news.bg/bulgaria/ekshan-v-plovdiv-nad-1000futbolni-fenove-hvarlyat-bombi-i-blokirat-ulitsi.html, 25 Mart 2020.

"Fourth Opinion on Bulgaria, ACFC/OP/IV(2020)001Final (Advisory Committee On The Framework Convention For The Protection Of National Minorities)", 26 May1s 2020 (Çevrimiçi), https://rm.coe.int/4th-op-bulgaria-en/16809eb483, 22 Ekim 2020. “Gayrimenkullerin Geri İadesi Yasası, 1992”, 1992 (Çevrimiçi), Lex.bg, https://www. lex.bg/laws/ldoc/2132811266, 21 Temmuz 2020.

"GERB se otkaza da oproshtava dilgovete [GERB borçları affetmekten vazgeçti]", Kapital, 13 Mart 2019 (Çevrimiçi), https://www.capital.bg/politika_i_ikonomika/ bulgaria/2019/03/13/3403981_gerb_se_otkaza_da_oproshtava_dulgovete_na/, 13 Nisan 2020.

"HASAN and CHAUSH v. Bulgaria, no. 30985/96 (Grand Chamber Judgment)", 26 Ekim 2000 (Çevrimiçi), https://www.echr.coe.int/Pages/home.aspx?p=home, 28.10.2020.

"Karlovtsi plaşat s grajdansko nepodçinenie [Karlıvalılar sivil itaatsizlik ile tehdit ediyor]", Standart, 15 Kasım 2013 (Çevrimiçi), https:/www.standartnews.com/ lifestyle-lyubopitno/karlovtsi_plashat_s_grazhdansko_nepodchinenie-214105.html, 22 Mart 2020.

"Kmet na Karlovo: Zadava se burya - muftiystvoto prevzema 10\% ot Bilgaria [Karliova belediye başkanı: Fırtına geliyor - Müftülük Bulgaristan'ın \%10'una el koyuyor]', Dimitrovgrad Bgvesti, 5 Aralık 2013 (Çevrimiçi), https://www.dimitrovgrad.bgvesti. net/news/144618/kmett-na-karlovo-zadava-se-burya-myuftiystvoto-prevzema-10ot-B1lgariya, 25 Mart 2020.

"Parliamentary questions, E-4794/2010, Answer given by Mrs Reding on behalf of the Commission", 27 Ekim 2010 (Çevrimiçi), https://www.europarl.europa.eu/sides/ getAllAnswers.do?reference=E-2010-4794\&language=EN, 10 Nisan 2020. 
"Parliamentary questions, E-4794/2010, Question for written answer to the Commission, Rule 117, Metin Kazak (ALDE), Carl Haglund (ALDE) and Sophia in 't Veld (ALDE)", 30 Haziran 2010 (Çevrimiçi), https://www.europarl.europa.eu/ sides/getDoc.do?pubRef=-//EP//TEXT+WQ+E-2010-4794+0+DOC+XML+V0// EN\&language $=\mathrm{EN}, 10$ Nisan 2020.

"Protest sreştu promenite v zakona za veroizpovedaniyata v Sofiya [Sofya'da Dinler Kanunu değişikliklerine karşı protesto]”, Nova, 11 Kasım 2018 (Çevrimiçi), https:// cutt.ly/rbDbs3U, 21 Ocak 2020.

"Sofya Şehir Mahkemesi 24 Ocak 2016 tarihli kurultay kararlarını onayladı", 10 Şubat 2016 (Çevrimiçi), Bulgaristan Başmüftülüğü, https://www.grandmufti.bg/bg/upto-date/novini/2218-sofiiski-gradski-sad-registrira-natzionalnata-myusyulmanskakonferentziya-ot-24-yanuari-2016.html, 8 Eylül 2020.

"Ultrasi Troşat Djamiata v Plovdiv [Aşırı milliyetçiler Filibe camisine saldırd1]", Webcafe, 14 Şubat 2014 (Çevrimiçi), https://webcafe.bg/newscafe/1030750469ultrasi-troshat-dzhamiyata-v-plovdiv.html, 31 Mart 2020.

"Vıprosıt s Osmanskite imoti e ureden - uveri kulturniat ministır [Kültür Bakanı: Osmanlı mülkiyeti ile mesele halledildi]”, Darik News, 12 Ağustos 2013 (Çevrimiçi), https:/dariknews.bg/novini/bylgariia/vyprosyt-s-osmanskite-imoti-e-ureden-uverikulturniqt-ministyr-1128638, 1 Aralık 2020.

"Vrıştat ni v Osmanskata İmperiya [Osmanlı İmparatorluğu dönemine döndürülüyoruz]", Duma, 27 Eylül 2013 (Çevrimiçi), https://duma.bg/vrashtat-ni-v-osmanskataimperiya-n63361, 20 May1s 2020.

Çauşeva, Leyla: "Nesekvaştite opiti za promyana - prednaznaçenieto na Kurshun djamiya v Karlovo [Karlıova'da Kurşun Camii'nin statüsünü sonu gelmeyen değiştirme teşebbüsleri]”, 19 Ekim 2018 (Çevrimiçi), Bulgaristan Başmüftülüğü, http:/www.grandmufti.bg/bg/home/news-room/novini/6677-nesekvashtite-opiti-zapromyana-prednaznachenieto-na-kurshum-dzhamiya-v-karlovo.html, 20 Ekim 2020. Georgieva, İrina: "Sofiyskiya apelativen sıd otloji deloto za vakıfskite imoti [Sofya İstinaf Mahkemesi vakıf malları davasını erteledi]”, Bulgaria On Air, 24 Ekim 2014 (Çevrimiçi), https://www.bgonair.bg/bulgaria/2014-10-24/otlagat-deloto-zakurshum-dzhamiya, 11 Ocak 2020.

Gorçeva, Daniela: “Za 'Vizroditelniya protses' i sıprotivata sreştu nego triabva da pişe v uçebnitsite [Sözde "soyadönüş süreci” ve buna karşı direniş ders kitaplarına yazılmalıdır]", Liternet, 21 Aralık 2009 (Çevrimiçi), https://liternet.bg/publish19/d_ gorcheva/mihail-ivanov.htm, 2 Şubat 2020. 
Jelev, Zlatko: "Proektıtgotov! 5-etajna djamia v Sofia [Proje hazır! Sofya'da 5 katlı cami]", Dnes.bg, 26 Kasım 2008 (Çevrimiçi), https://www.dnes.bg/obshtestvo/2008/11/26/ proektyt-gotov-5-etajna-djamiia-v-sofiia.61564,12, 20 Şubat 2020.

Lübomirova, Desislava: "Myuftistvoto niama djamii, no ni predizvikva [Müftülüğün camisi yok, fakat bize meydan okuyor]", Actualno.com, 22 Nisan 2015 (Çevrimiçi), https://www.actualno.com/actualno/muftijstvoto-njama-djamii-no-ni-predizvikvanews_469021.html, 2 Aralık 2020.

Öztürk, Ayşe Zerrin: "Uluslararası İlişkiler Teorileri Arasında Normatif Teorinin Yeri ve Kapsamı”, Avrasya Dosyası, İstihbarat Özel, C.VIII, S.2, Yaz 2002 (Çevrimiçi), s. 427-444, https://www.researchgate.net/publication/330938169_ULUSLARARASI ILISKILER_TEORILERI_ARASINDA_NORMATIF_TEORININ_YERI_VE_ KAPSAMI, 29 Aralık 2020.

Petkova, Tanya: "DPS: Vlastta mılçalivo poddırja "uzurpatora" Nedim Gencev [Hükûmet "gaspçı" Nedim Gencev'i sessizce destekliyor]", Mediapool. bg, 24 Eylül 2010 (Çevrimiçi), https://www.mediapool.bg/dps-vlasttamalchalivo-poddarzha-uzurpatora-nedim-gendzhev-news 170351. html?fbclid=IwAR2rCMFZgeDcFeDV2MVwdKm9Nx8GYx9N1Dfj57YsSs QeZmWWbdrNIBKqgM, 21 Nisan 2020.

Stoilova, Zornitsa: "Kak B1lgarskite imami ostanaha bez pari [Bulgaristan imamları nasıl parasız kaldı]", Kapital, 8 Haziran 2017 (Çevrimiçi), https://www.capital. bg/politika_i_ikonomika/bulgaria/2017/06/08/2985260_kak_bulgarskite_imami_ ostanaha_bez_pari/, 20 Nisan 2020.

Stoyanova, Stela: "Zapeçataha Glavno Muftiystvo: Çasten Sıdeben İzpılnitel Vleze s Policiyata v Sgradata [Başmüftülüğü mühürlediler: Özel icra hakimi polisle birlikte binaya girdiler]", Dnes.bg, 27 Kasım 2010 (Çevrimiçi), https://www.dnes.bg/ obshtestvo/2010/11/27/zapechataha-glavnoto-miuftiistvo.104925,6, 29 Mart 2020.

Yordanova, Maya: "Kmetove se obedinyavat sreştu pretentsiite na müftiystvoto [Belediye başkanları müftülüğün taleplerine karşı birleşiyor]", Novini.bg, 30 Kasım 2013 (Çevrimiçi), https://novini.bg/bylgariya/obshtestvo/168654, 30 Nisan 2020. 
